\title{
O fortalecimento dos bancos comunitários a partir da organização em rede: o caso da Rede Baiana de BCDs
}

\section{The strengthening of the community banks from the network organization: the case of the Baiana Network BCDs}

\author{
MAGNO WILLAMS DE MACEDO FARIAS \\ ADRIANNE GARCIA \\ MARIA ELENA LEON OLAVE \\ Universidade Federal de Sergipe
}

\section{RESUMO}

As redes de economia solidária articulam os setores do Estado e as Sociedade Civil atuando na elaboração teórica e apoio a empreendimentos solidários. Este estudo teve como objetivo analisar como a Rede Baiana de BCDs contribui para o fortalecimento dos bancos comunitários da Bahia.. A metodologia aplicada neste estudo propõe uma abordagem qualitativa, de natureza descritiva e exploratória. Utilizou-se o estudo de caso como estratégia de pesquisa. Concluiu-se que a Rede Baiana tem colaborado de forma significativa para superar os desafios enfrentados pelos bancos, permitindo que seus participantes possam se articular, compartilhar informações, trocar experiências, receber auxilio técnico e acessar recursos. Suas ações, de modo geral, têm fortalecidos os bancos existente dando maior visibilidade e ampliando sua oferta de serviços, além de atuar no apoia a expansão dessas experiências com a constituição de novos bancos, fortalecendo o movimento de economia solidária, como também a própria rede. Palavras-chave: Redes; Redes de Economia Solidária; Bancos Comunitários 


\section{Abstract}

Solidarity economy networks articulate the sectors of the State and Civil Society acting in the theoretical elaboration and support to solidary enterprises. This study aimed to analyze how the Bahia BCD Network contributes to the strengthening of community banks in Bahia. The methodology applied in this study proposes a qualitative, descriptive and exploratory approach. The case study was used as a research strategy. It was concluded that the Baiana Network has collaborated significantly to overcome the challenges faced by banks, allowing its participants to articulate, share information, exchange experiences, receive technical assistance and access resources. Its actions, in general, have strengthened the existing banks, giving greater visibility and broadening its offer of services, besides acting in support of the expansion of these experiences with the constitution of new banks, strengthening the solidarity economy movement, as well as the network itself.

Keywords: Network organization; Solidary economy; Community banks.

\section{INTRODUÇÃo}

O sistema econômico tradicional vem dando sinal de falência e seu modelo de desenvolvimento baseado na acumulação da riqueza por parte de uma minoria e exclusão do sistema financeiro da grande parcela da população mundial vem contribuindo para aumentar a crise do trabalho. Como resposta a este modelo, alternativas de desenvolvimento veem sendo pensadas e implementadas, alternativas estas que buscam um novo modelo de desenvolvimento e novas formas de geração de trabalho e renda (CASSANDRE et al., 2013).

Uma das alternativas que vem despontando em diversas formas de organizações, inclusive sociais, são as redes de economia solidária, que segundo Mance (1999) são organizações sociais de caráter econômico, político e cultural, que, sob aspectos econômicos, articulam grupos de consumidores, produtores e prestadores de serviços em laços de realimentação. Tais redes articulamos setores do Estado e da Sociedade Civil atuando na elaboração teórica e apoio a empreendimentos solidários (HIGA, 2005). Além disso, essas podem ser vistas como uma estratégia para integrar grupos de 
consumo, cooperativas, sindicatos, movimentos populares, grupos de produção, e outros, de maneira tal que todos possam se fortalecer e avançar juntos, construindo uma nova sociedade, sendo também uma alternativa ao combate da economia informal (HART, 1973; GODFREY, 2011).

No Brasil, em 2003, o Governo Federal auxiliou no fomento dessas redes de economia local, criando a Secretaria Nacional de Economia Solidária (SENAES), que é um instrumento para identificação e registro de informações de empreendimentos econômicos solidários, entidades de apoio e fomento à economia solidária e políticas públicas de economia solidária no Brasil (Ministério do Trabalho, 2013).

A SENAES teve papel importante no fomento de iniciativas de apoia a geração de trabalho e renda nas camadas mais pobres da população, como também no fomento a empreendimentos de finanças solidarias como cooperativas de créditos solidárias, fundos rotativos solidários e bancos comunitários, através de editais públicos, com vistas a inclusão financeira dessa população ( RIGO; FRANÇA FILHO; LEAL, 2015). Segundo dados do IPEA/SIPS (2011), 39,5\% da população brasileira não possui conta bancária. Na região Nordeste, esse quadro se agrava alcançando 52,6\%. Os bancos comunitários de desenvolvimento protagonizam como alternativa no combate a essa exclusão, proporcionando às comunidades um desenvolvimento econômico antes deficiente. O primeiro banco comunitário surgiu em Fortaleza em 1998 e recebeu o nome de Banco Palmas. Em 2013 esses bancos somaram-se 103 iniciativas espalhadas por diversos municípios de diferentes estados brasileiros. Essas instituições vêm se articulando em rede desde de 2004, quando foi criada a Rede Brasileira de Bancos Comunitários. Além da Rede Brasileira, também surgiram ao longo dos últimos anos redes estaduais e regionais de bancos comunitários, como a Rede Nordeste de BCDs, a Rede Cearense, a Rede Capixaba e a Rede Baiana. A Rede Baiana foi criada em 2010 e conta hoje com oito bancos comunitários.

Nesse contexto, esse estudo tem como objetivo analisar como a Rede Baiana de BCDs contribui para o fortalecimento dos bancos comunitários da Bahia. Foram elencados objetivos específicos norteadores para alcançar o objetivo proposto: (1) entender a forma de or- 
ganização e gestão da Rede Baiana de BCDs; (2) mapear as principais atividades da rede desde a sua criação; (3) identificar os principais benefícios alcançados pela rede de forma coletiva e (4) verificar os benefícios alcançados individualmente para os 05 BCDs entrevistados.

$\mathrm{O}$ artigo apresenta-se estruturado da seguinte maneira: revisão da literatura dividida em dois tópicos: Redes de Economia Solidária e Bancos Comunitários de Desenvolvimento, seguindo para o detalhamento dos procedimentos metodológicos. Em seguida, será realizada caracterização das empresas estudadas, junto a análise dos dados coletados, finalizando com as conclusões baseadas nos dados analisados e sugestões para pesquisas futuras.

\section{REDES DE ECONOMIA SOLIDÁRIA}

Com o fortalecimento do capitalismo gerencial no século XIX, as organizações empresariais passaram a ser caracterizadas pela burocratização e pela alta competição. Porém, o cenário econômico do mercado sofre transformações no final do século XX, estabelecendo modificações na maneira como os negócios eram conduzidos (VERSCHOORE, 2006). As pressões exercidas pelo mercado, que se tornou cada vez mais competitivo, fizeram surgir as organizações coletivas de livre iniciativa ou fomentadas por órgãos agenciadores de desenvolvimento que somadas as pressões de necessidades sociais em determinadas regiões do país, a exemplo da necessidade de desenvolvimento econômico de comunidades, promoveram a confecção de uma teia que entrelaça pessoas, organizações e objetivos (GUARDA, 2010). As competências exigidas pelos consumidores do século XXI obrigaram as empresas e organizações a desenvolver um modelo de cooperação entre si, a fim de que fossem capazes de suprir as lacunas existentes em seus negócios (CASTELLS, 1999; VERSCHOORE, 2006).

Para Guarda (2010) esses fatores remetem essas organizações a buscarem sua complementariedade, articulando forças em redes. Segundo Macieirinha (2009), uma rede é composta por atores que visam um objetivo comum, com prazo indeterminado, que participam diretamente das decisões, beneficiando-se dos ganhos e benefícios igualitariamente, tudo isso sem que a sua individualidade seja extinta. A noção de rede coloca ênfase nas relações entre diversidades que se integram, nos fluxos de elementos que circulam nessas relações, nos laços que potencializam a sinergia coletiva, no movimento de 
auto-organização em que cada elemento auxilia no desenvolvimento do outro, na potencialidade de transformação de cada parte pela sua relação com as demais e na transformação do conjunto pelos fluxos que circulam através de toda rede (MANCE, 2002).

Minhoto e Martins (2001) identificaram alguns pré-requisitos para a formação das redes: preexistência de um conjunto de organizações criadas para propósitos específico; preexistência de conjunto de órgãos instituídos para propósitos específicos, que são distribuídos por esferas e setores do governo; situações-problemas que requerem a intervenção por agente interorganizacional ou intersetorial; articulação com o objetivo de desenvolver formas de atuação conjunta e de cooperação para o enfrentamento de situações, ainda que mantida a autonomia de cada ente; e a manutenção da identidade de cada ente e suas atividades específicas.

Atualmente, o modelo de redes é bastante difundido entre diversas esferas da sociedade, inclusive em organizações sociais, tal qual apontam os trabalhos de Siqueira, Vieira e Carmona (2013) e de Siqueira, Costa e Vieira (2017). Dowbor (2008, p.98) afirma que "as atividades hoje se tornaram muito mais amplas, complexas e interativas, fazendo com que as economias de colaboração, materializadas no capital social, sejam cada vez mais importantes". Guarda (2010) sugere que a rede de cooperação tomou seu espaço nas diversas formas de organização, sejam elas empresariais com finalidades econômicas, sociais, sem o com fins lucrativos, e principalmente redes de cooperação solidaria com objetivo de construir outras lógicas de produção, consumo e articulação política.

Essas redes de economia solidária, segundo Mance (2003), podem ser vistas como uma estratégia para integrar grupos de consumo, cooperativas, sindicatos, movimentos populares, grupos de produção, e outros, de maneira tal que todos possam se fortalecer e avançar juntos, construindo uma nova sociedade. Para França Filho e Cunha (2009), as redes locais de economia solidária ${ }^{1}$ desenvol-

\footnotetext{
${ }^{1}$ França Filho e Laville (2004, p.15) define economia solidária como uma outra economia que se gesta em diferentes partes do mundo a partir de iniciativas, sobretudo de natureza cooperativista e associativista, oriundas da sociedade civil e dos meios populares. Tais iniciativas assumem diferentes configurações, desde aquelas que criam o seu próprio circuito de produção e consumo, alimentando cadeias sócio-produtivas autônomas e, em alguns casos, fortemente baseadas em relações não-monetarizadas, até outras que empreendem relações mais permanentes com o mercado e desenvolvem diferentes tipos de parcerias com os poderes públicos.
} 
vem um papel fundamental na restruturação da economia local de uma comunidade. Essas redes locais são compostas pela associação de vários empreendimentos coletivos que visam a construção de um circuito próprio de relações econômicas, troca de experiências, informações sobre atividades e outras organizações, rede de contatos, além da redução de custos fixos em determinadas situações (FRANÇA FILHO; CUNHA, 2009; BRAZ; CARDOSO, 2013). Para que a cooperação em redes de empreendimentos solidários seja eficaz, é necessário que haja confiança e valorização mútua entre os indivíduos, pressupondo a existência de relacionamentos interpessoais baseados em laços (GRANOVETTER, 1973; BRAZ; CARDOSO, 2013).

As redes de economia solidária também se mostram como uma alternativa ao combate da economia informal, que é consequência de problemas sociais e que tem se solidificado enquanto movimento econômico (HART, 1973; GODFREY, 2011). Gaiger (2009), em seu estudo sobre associação econômica dos pobres como via de combate às desigualdades, sugere que o termo "economia solidária" refere-se a práticas econômicas de pessoas associadas livremente, cujas características em comum são: (1) algum grau de socialização dos meios de produção; (2) dispositivos de cooperação no trabalho; (3) elementos de gestão democrática; (4) envolvimentos em ações mais amplas, a partir do entorno dos empreendimentos (LAVILLE; GAIGER, 2009). Essas práticas também vêm sendo estudadas em outros países da América Latina e do mundo (CORAGGIO, 2012).

Segundo Mance (2002) quatro são os critérios básicos de participação nas redes de Economia Solidária:

1) que nos empreendimentos não haja qualquer tipo de exploração do trabalho, opressão política ou dominação cultural; 2) busque-se preservar o equilíbrio ecológico dos ecossistemas (respeitando -se todavia a transição de empreendimentos que ainda não sejam ecologicamente sustentáveis); 3) compartilhar significativas parcelas dos excedente para expansão da própria rede; 4) autodeterminação dos fins e autogestão dos meios, em espírito de cooperação e colaboração.

Essas redes podem abranger uma série de empreendimentos e iniciativas em distintos campos na sua base territorial, como: de 
consumo ético, finanças solidárias, tecnologias livres, comércio justo, produção autogestionária ${ }^{2}$ e serviços locais, entre outros, além da articulação dos atores externos governamentais e não-governamentais. Neste sentido, supõe haver nessas redes, "articulações entre iniciativas de distintas naturezas - socioeconômicas, sociopolíticas, socioculturais e socioambientais. Além disso, ela admite diferentes níveis de articulação com a economia local preexistente (FRANÇA FILHO; CUNHA, 2009b)".

Os bancos comunitários, no campo das finanças solidárias, vêm se articulando em rede desde 2004, quando foi criada a Rede Brasileira de Bancos Comunitários. Segundo Rigo e Cansado (2015), a Rede Brasileira de BCDs atualmente é o principal espaço público criado e utilizado pelos BCDs no tocante ao processo de institucionalização e sustentabilidade das iniciativas por todo o país. Ainda segundo Rigo e Cansado (2015) é nesse espaço que vem sendo discutida a importância da criação de um marco legal regulatório para os BCDs e o uso de moedas sociais. Além das formas de apoio e financiamento público.

Além da Rede Brasileira, também surgiram ao logo dos últimos anos redes estaduais e regionais de bancos comunitários, como a Rede Nordeste de BCDs, a Rede Cearense, a Rede Capixaba e a Rede Baiana. A Rede Baiana foi criada em 2008 e conta hoje com oito bancos comunitários.

\subsubsection{Bancos Comunitários de Desenvolvimento (BCDs)}

O primeiro banco comunitário no Brasil surgiu em 1998 na periferia de Fortaleza no Ceará. Desde seu surgimento o Banco Palmas tem incentivado o desenvolvimento de novos bancos comunitários. Os bancos comunitários de desenvolvimento (BCDs) podem ser definidos como uma prática de finanças solidárias de apoio a economias populares de territórios com baixo índice de desenvolvimento humano (FRANÇA FILHO e SANTANA, 2013; FREIRE, 2013; FRANÇA FILHO, 2013). Para Melo Neto e Magalhães (2007) os BCDs são serviços financeiros solidários em rede, de natureza associativa e comunitária, voltados para geração de trabalho e renda, tendo por base os princípios da Economia Solidária. 
Segundo os dados do último mapeamento do Sistema Nacional de Economia Solidária (SIES) realizado em 2012 existem hoje 19708 empreendimentos de economia solidária, dos quais 40,8\% estão localizados na região Nordeste. Dentre o total de empreendimentos $1,7 \%$ estão classificados como de poupança, crédito ou finanças solidárias, entre estes 103 são Bancos Comunitários de Desenvolvimento. Baseando-se numa lógica de economia solidária, “os BCDs ratificam a construção de uma outra economia, cuja a vocação maior é de produção e preservação da vida num determinado contexto territorial, conforme o significado original da economia" (FRANÇA FILHO, 2010, p.4). Melo Neto e Magalhães (2007) argumentam que a própria comunidade é quem decide criar o banco, e dele se torna gestora e proprietária. Suas linhas de crédito estimulam a criação de uma rede, uma vez que apoiam a comercialização local, atuando em territórios caracterizados por exclusão, vulnerabilidade e desigualdade social.

Ao argumentar sobre a finalidade de um BCD, Singer (2013) aponta que seu objetivo não é maximizar seu lucro, como fazem os bancos privados, mas fomentar o desenvolvimento de comunidades que o criou e o utiliza. Este argumento ganha corpo quando apresentada as características dos BCDs que os distinguem dos bancos convencionais e de outras iniciativas financeiras como as cooperativas de créditos.

Estas iniciativas ao confirmar seu potencial em promover uma efetiva inclusão financeira, principalmente ao atingir a população de mais baixa renda, principalmente as excluídas do sistema financeiro podem ser vistas, segundo Rigo (2014) como instituições criadas para ocupar um espaço deixado por um movimento de afastamento do mercado em relação à sociedade; ou ainda, de uma parcela da sociedade que a maioria das instituições financeiras de mercado não se interessa por integrar.

Segundo França Filho (2010), a ousadia de um BCD é de tentar restaurar laços e vínculos sociais seriamente degradados pelas condições de vidas mais geral das pessoas nos bairros populares, por meio de um novo tipo de relação com o dinheiro e organização da vida econômica local. Para tal propósito essas iniciativas contam com uma lógica de funcionamento e gestão fundado na participa- 
ção democrática e empoderamento das pessoas no seu processo de gestão (FRANÇA FILHO, 2010). Melo Neto e Magalhães (2007, p. $8)$, adicionam, que "os BCDs são geridos no interior de estruturas de organizações de caráter comunitário (como associações, fóruns, conselhos) ou outros tipos de organização da sociedade cível que estão inseridas na comunidade (igrejas, sindicatos, ONGs). Seu funcionamento supõe, portanto, a constituição de uma equipe de coordenação executiva no seio da própria organização associativa. Sua gestão implica desse modo numa dimensão compartilhada com forte componente de controle social local baseado em mecanismo de democracia direta".

Tal gestão possui três importantes atores (instâncias) que atuam diretamente na execução das atividades e nas decisões do BCD e estão fortemente ligadas. O primeiro é representado pelo(a)s agentes de crédito responsáveis pelo funcionamento do BCD no seu dia-a-dia. O segundo é composto pelo Comitê de Avaliação de Crédito (CAC) responsável pela análise das solicitações crédito, podendo aprová-las ou não, e o terceiro é o Conselho Gestor, que representa a instância máxima de decisão, formada por representantes do BCD e representantes das entidades parceiras, responsáveis pelas decisões mais estratégicas e diretrizes maiores do empreendimento.

Outro ponto a ser destacado na dinâmica de criação e funcionamento de um BCD está relacionado com a sua sustentabilidade. Segundo França Filho e Santana (2013) o modo como os BCDs se mantém repousa sobre uma articulação de diferentes lógicas de organização econômica, o que torna incompatível sua sustentabilidade sob a égide do conceito convencional de viabilidade econômica, o que o torna totalmente dependente de recursos do seu ambiente externo. Segundo Melo Neto e Magalhães (2007, p. 9) "sua sustentabilidade se dá por meio da capitação de recursos públicos e da constituição de um fundo solidário investimento comunitário". Ainda segundo Melo Neto e Magalhães (2007), esse tipo de fundo constitui-se de múltiplas fontes de recurso, entre pessoas físicas, pessoas jurídicas, cotização de associados, prestações de serviços, realização de eventos (show de prêmios, bingos e outros).

A dificuldade em consolidar-se como empreendimento autossustentável tem levado a boa parte destas iniciativas a reduzirem 
sua capacidade de atuação ou até mesmo paralisar temporariamente suas atividades. Rigo (2014) ao investigar a situação atual dos BCDs no Brasil, identificou que apenas 59,6\% estavam em pleno funcionamento. Entre os 40,4\% restantes, 29,8\% estavam funcionado parcialmente, ou seja, o BCD havia diminuído suas atividades e o atendimento às solicitações de crédito, mas continuava aberto ao público e gerenciando os recursos, a circulação da moeda social e outras atividades relativas aos projetos sociais, e 10,6\% estavam temporariamente sem atividade.

Ainda segundo Rigo (2014) no caso dos BCDs da região Nordeste, quase a metade dos BCDs investigados não tem funcionado plenamente. Os principais motivos identificados pela autora para essa realidade foram a falta de fundo de crédito, dificuldades relativas à circulação e ao empréstimo com a moeda social e dificuldades para pagamento das despesas. Na Bahia atualmente existem 8 bancos comunitários, mas destes, apenas 4 estão em pleno funcionamento, 1 encontra-se funcionando parcialmente e 3 estão com suas atividades temporariamente paralisadas.

Diante das dificuldades enfrentadas por estes BCDs existem alguns elementos que apontam para sua reorganização de forma que estes se apoiem mutuamente. Essa reorganização ocorre, principalmente, pelos processos de fortalecimento regionais, a exemplo da rede estadual de bancos na Bahia, a rede do Espirito Santo e a rede Cearense.

\section{Metodologia}

A metodologia aplicada neste estudo propõe uma abordagem qualitativa, de natureza descritiva e exploratória. Utilizou-se o estudo de caso como estratégia de pesquisa, que segundo Yin (2015), é adequado para análises que não necessitam controle sobre eventos comportamentais, mas focalizam acontecimentos contemporâneos, para descrição de dada realidade social (VIEIRA; RIVERA, 2012). Dentro desse conceito, optou-se pelo estudo de caso único integrado, que se apresenta como uma escolha quando, em um caso único, a atenção também é dirigida a subunidades de análise (YIN, 2015). Como fundamento para a utilização dessa estratégia de pesquisa foram observados dois aspectos:

a) Escassez de informação sobre o tema; 
b) Complementaridade de informações quando analisadas as subunidades da Rede observada.

O critério de escolha do caso foi acessibilidade dos pesquisadores à rede. Como unidade de análise desse estudo, foi selecionada a Rede Baiana de Bancos Comunitários de Desenvolvimento, formada atualmente por 7 (sete) bancos comunitários de desenvolvimento, o Banco Casa do Sol da comunidade de Cairu, em Cairu; Banco Eco-Luzia da comunidade de Santa Luzia, em Simões Filho; Banco Quilombola do Iguape, na comunidade de Iguape, em Cachoeiras; Banco BAMEX em Canavieiras; Banco Abrantes Solidário na comunidade de Vila do Abrantes, em Camaçari; Banco Amigos do Sertão no distrito de Morrinhos, em Guanambi e Banco Ilhamar da comunidade de Matarandiba, em Vera Cruz, e pela Incubadora Tecnológica de Economia Solidária e Gestão do Desenvolvimento Territorial (ITES/UFBA), dos quais 6 (seis) serão as subunidades de análise do estudo.

Segundo Eisenhardt (1989), os estudos de caso combinam métodos de coleta de dados, tais como arquivos, entrevistas, questionários e observações. Dessa forma, quanto à coleta de dados, o estudo baseou-se em entrevistas individuais semiestruturadas, realizada com os agentes locais de desenvolvimento dos bancos escolhidos. Segundo Laville e Dionne (1999: p.188) a entrevista semiestruturada permite a realização de uma série de perguntas abertas, feitas verbalmente em uma ordem prevista, mas na qual o entrevistador pode acrescentar perguntas de esclarecimentos. Ela ainda permite que o entrevistado formule uma resposta pessoal, obtendo uma ideia melhor do que esse realmente pensa e se certifica na mesma ocasião de sua competência. Sua flexibilidade possibilita um contato mais íntimo entre entrevistador e entrevistado, favorecendo assim a exploração em profundidade de seus saberes, bem como de suas representações, crenças e valores (LAVILLE; DIONNE, 1999, p. 189). Foi realizado ainda pesquisa documental de relatórios da Rede Baiana de BCD, que segundo Godoy (1995) constitui uma rica fonte de dados.

Para a escolha dos entrevistados levou-se em consideração o tempo de pertencimento do banco na Rede e sua ativa participação. Assim foram entrevistados os representantes dos BCDs que fazem parte da rede a mais de um ano e que seu representante tenha participado de no mínimo 4 encontros da rede nos últimos dois anos. Esses critérios justificam-se, primeiro devido ao fato de que um banco que esteja 
a menos de uma ano na rede não tenha se apropriado de todos os processos, não sendo assim possível identificar os benefícios da participação em rede, tanto coletivamente, como também individualmente. Em segundo lugar o banco que não tenha participado ao menos de quatro reuniões nos últimos dois anos não teria como identificar quais tem sido os benefícios alcançados pela rede baiana nos últimos anos, como também não saberá informar qual estágio atual da mesma. Por esses critérios deixaram de participar desta pesquisa o Banco Amigos do Sertão, que ingressou na rede no último dia 18, após sua inauguração, e o Banco Comunitário Santa Luzia que, embora seja um dos fundadores da rede, não vem participando da mesma desde de 2014, quando teve suas atividades parcialmente paralisadas.

No tocante às categorias de análise, foram definidas, com base nos objetivos, as seguintes:

\section{Quadro 1: Categorias e elementos de análise}

\begin{tabular}{|l|l|}
\hline Categorias de análise & Elementos de análise \\
\hline $\begin{array}{l}\text { Organização da rede local de econo- } \\
\text { mia solidária }\end{array}$ & $\begin{array}{l}\text { Descrever estrutura da rede; mapear } \\
\text { atividades. }\end{array}$ \\
\hline Benefícios da rede & $\begin{array}{l}\text { Benefícios alcançados pela rede; } \\
\text { benefícios alcançados individualmente } \\
\text { pelos bancos por meio da rede por } \\
\text { meio das redes. }\end{array}$ \\
\hline Percepções sobre a Rede Baiana & $\begin{array}{l}\text { Situação atual da rede (fortalecimento } \\
\text { ou fragilidade); desafios e dificulda- } \\
\text { des para sua manutenção. }\end{array}$ \\
\hline
\end{tabular}

Fonte: Elaborado pelos autores.

Quadro 2: resumo dos procedimentos metodológicos.

\begin{tabular}{|l|l|}
\hline Abordagem & Qualitativa \\
\hline Natureza & Descritiva \\
\hline Estratégia de pesquisa & Caso único integrado \\
\hline Coleta de dados & $\begin{array}{l}\text { Entrevista semiestruturada e análise docu- } \\
\text { mental }\end{array}$ \\
\hline Unidade de análise & Rede Baiana de Bancos Comunitários \\
\hline
\end{tabular}

Fonte: Elaborado pelos autores. 
Após a coleta dos dados, as entrevistas gravadas foram transcritas e utilizou-se a técnica da análise de conteúdo para a análise das informações captadas. Para o tratamento das informações obtidas utilizou-se a técnica de análise de conteúdo. De acordo com Laville e Dionne (1999: p.205) a análise de conteúdo permite abordar uma grande diversidade de objetos de investigação como: atitudes, valores, representações, mentalidades, ideologias, entre outros.

\section{DESCRIÇÃo E ANÁliSE dOS CASOS}

Nessa seção, foi feita a descrição da Rede Baiana de Bancos Comunitários de Desenvolvimento, suas atividades e seus princípios. Em seguida, a descrição dos bancos e a análise do conteúdo obtido por meio das entrevistas, norteadas pelas categorias de análise dispostas no Quadro 01.

\subsection{Rede Baiana de Bancos Comunitários de Desenvolvimento}

A Rede Baiana de Bancos Comunitários foi fundada em 2010 pelos bancos comunitários do Estado da Bahia. Na ocasião fizeram parte da criação da rede os quatro banco existentes no período, banco ILHAMAR, banco Casa do Sol, banco Guine, Banco Santa Luzia, além da ITES/EAUFBA. O objetivo da rede é fortalecer as ações dos BCDs promovendo meios de apoio e suporte técnico, e através de intercâmbio de experiências, parcerias e da participação das comunidades na definição de estratégias próprias, promovendo os princípios da economia e das finanças solidárias para desenvolver as comunidades locais, propondo ações e políticas públicas de BCDs. Além disso, promove discussões envolvendo questões relativas à gestão e operação de BCDs, orientações e estratégias para o desenvolvimento comunitário, superação das desigualdades e geração de emprego e renda.

Hoje, a rede conta com a entidade de fomento ITES/EAUFBA e com sete bancos comunitários: Banco Casa do Sol da comunidade de Cairu, em Cairu; Banco Eco-Luzia da comunidade de Santa Luzia, em Simões Filho; Banco Quilombola do Iguape, na comunidade de Iguape, em Cachoeiras; Banco BAMEX em Canavieiras; Banco Abrantes Solidário na comunidade de Vila do Abrantes, em Camaçari; Banco Amigos do Sertão no distrito de Morrinhos, em 
Guanambi e Banco Ilhamar da comunidade de Matarandiba, em Vera Cruz. Além desses bancos, mais três bancos, prestes a inaugurar, estão em processo de credenciamento para compor a rede, são eles: Banco Ouro Negro em São Francisco do Conde; Banco Uruguai no bairro do Uruguai, em Salvador e o Banco Dois de Julho, em Caetité. Ao longo dos anos deixaram de fazer parte da rede o banco Guine da comunidade de Saramandaia, em Salvador, que encerrou suas atividades em 2014, e o banco Fonte de Agua Fresca da cidade de Ouriçangas, que deixou de operar como banco comunitário e hoje atua apenas como correspondente bancário da caixa econômica.

Em 2011, foi realizado o I Encontro de Comunicação da Rede Baiana de BCDs, em que foi apresentada a carta de princípios da Rede Baiana, com as seguintes orientações: (1) Envolver o maior número possível de pessoas da comunidade em ações solidárias, construtivas e responsáveis com o objetivo de um retorno positivo ao consumo responsável e a reeducação ambiental; (2) Trabalhar em grupo com a comunidade, procurando sempre envolvê-la em decisões, para firmar compromissos de confianças, entre entidades e comunidade; (3) Procurar e manter parceiros ou colaboradores que se disponibilizem a sustentar e desenvolver propostas não apenas no lado financeiro, mas também com ideias e ações mais que reforcem as relações sociais; (4) Acreditar sempre que nem só a boa intenção muda o mundo, e sim a paixão e o prazer em fazer promovendo a mudança tão esperada e tão merecida para aqueles que acreditam e apoiam à causa da Economia Solidária; (5) Contribuir no processo de construção de uma sociedade justa, democrática e solidária com relações de gênero, no meio ambiente, através das ações de intervenção e produção de conhecimentos direcionados para apoio e fortalecimento da Economia Solidária; (6) Criar na comunidade o trabalho coletivo-cooperativo que possibilite um modelo de fraternidade comunitária; (7) Trabalhar em um sistema de autogestão; (8) Conscientizar entidades (capitalistas) e a sociedade sobre práticas solidárias; (9) Considerar que o Banco pertence à comunidade, onde todos são iguais, independente de raça, cor ou religião, destacando a confiança como princípio norteador; (10) Trabalhar em parceria, cooperação e associativismo para formação e fortalecimento da Rede; (11) Ter o ser humano como centro das 
relações econômicas, visando o bem-estar de todos e de cada um; (12) Promover o desenvolvimento pessoal em Economia Solidária; (13) Colaborar com o desenvolvimento cultural da comunidade; (14) Orientar a comunidade sobre aspectos de gestão dos recursos próprios/educação financeira; (15) Socializar as práticas e experiências dos Bancos Comunitários de Desenvolvimento nas comunidades.

Além dessas orientações, também foi desenvolvido o acordo de convivência entre os bancos na Rede. São elencados como compromisso dentro da rede, a saber: companheirismo, humildade, solidariedade, responsabilidade, disponibilidade e compreensão entre os componentes da Rede. Os encontros das redes acontecem quatro vezes ao ano, em cada comunidade, sob o critério de prioridade, estabelecido pela própria rede. A coordenação da Rede é composta por um representante de cada uma das instituições que a compõe, sendo um (01) representante de cada BCD e um (01) representante da ITES/EAUFBA. Todos tem poder de voto e as decisões são tomadas coletivamente, regidas por princípios de autogestão ${ }^{2}$ e tendo como atribuições: (1) organizar encontros da rede; (2) Captação de recursos próprios para a rede; (3) Representar a Rede nos espaços de discussão da Economia Solidária; (4) Organizar as atividades de secretaria da Rede; (5) Buscar e disseminar informações sobre fontes de financiamento, parcerias e demais dados úteis à Rede.

\subsection{Os Bancos e a ITES/EAUFBA}

Na sequência são descritos os casos tendo como base as categorias analíticas adotadas no presente estudo (quadro 01).

\subsubsection{Incubadora Tecnológica de Economia Solidária e Gestão do Desenvolvimento Territorial (ITES/EAUFBA).}

A ITES é um programa de extensão da Universidade Federal da Bahia criado oficialmente em 2008 com objetivo de realizar

\footnotetext{
2 Rigo (2014) argumenta que o" termo autogestão refere-se à busca e à configuração de processos ou modos organizacionais justos e democráticos, onde os membros de uma organização coletiva (empreendimentos de economia solidária, por exemplo) estão engajados nos processos de tomada de decisão, atividades e controles organizacionais". Ainda Segundo Rigo (2014) a autogestão não significa apenas a autonomia da governança e do processo decisório exercido pelos membros da associação. A prática autogestionária, em sua essência, representa a construção cotidiana da autonomia dos associados, rompendo com qualquer prática autoritária.
} 
assessoria a projetos de redes de economia solidária em diversos territórios empobrecidos do Estado da Bahia. Sua origem vincula-se a Escola de Administração da UFBA. Ao longo dos anos a ITES tem se voltado para elaboração e execução de projetos destinados a constituição de redes locais de economia solidária. Seu processo de incubação apoia à constituição e gestão de diferentes tipos de empreendimentos e iniciativas articuladas em redes, a exemplo dos bancos comunitários de desenvolvimento. O Banco Comunitário Santa Luzia, localizado na comunidade de Santa Luzia na cidade de Simões Filho, foi o primeiro empreendimento desta natureza apoiado pela incubadora. Hoje, a ITES apoia 30 bancos comunitários espalhados por sete estados da região Nordeste, dos quais 10 se encontram no estado da Bahia. A incubadora também atua como membro em diversos espaço de articulação como a Rede Brasileira de Bancos Comunitários, a Rede Nordeste e a Rede Baiana, na qual é membro e fundadora. Outras organizações que se relacionam ou já se relacionaram com a rede são as prefeituras, empresas que apoiam os bancos, os fóruns (Fórum Baiano de Economia Solidaria e Grupos de Trabalho), e os financiadores: SETRE, FAPESB, FUNDO CASA.

Nesse estudo, foi entrevistada a técnica da incubadora que acompanha a Rede Baiana. Sobre o funcionamento da Rede Baiana, sob a perspectiva da ITES/EAUFBA, os bancos-membro estão todos em um mesmo patamar, tendo o mesmo poder de voto e participação igualitária, porém, apesar de a rede tentar se organizar de maneira cada vez mais descentralizada, conscientizando os bancos sobre o seu papel, a ITES continua sendo a principal condutora dos processos.

Em relação à definição de pautas em reuniões e tomada de decisão, por exemplo, A ITES tem majoritariamente sido a condutora, mas com o tempo e o entrosamento entre os bancos (representados pelos seus agentes de crédito), essa participação tem aumentado. De acordo com o discurso da entrevistada, a instituição tem intencionalmente incentivado maior participação dos bancos na rede, principalmente em relação à gestão, de forma a descentralizar e distribuir ainda mais a responsabilidade. 
“Às vezes, a participação dentro dos encontros fica restrita a poucas pessoas. Normalmente quem puxa as reuniões, quem dá as boasvindas, quem propõe pauta é sempre a ITES. Até hoje foram poucos os momentos quem eles conduziram um evento (...) Eu sinto que sempre alguma pessoa da ITES centraliza alguma responsabilidade ou acaba solicitando alguma demanda para o resto do grupo (...) se você não puxar algo, por eles mesmos não acontece (...). A gestão se propõe a ser horizontal dentro da rede, onde todos têm o mesmo poder de voto, tem total autonomia pra decisão, mas acaba que os representantes da incubadora acabam puxando o processo (...)".

O cenário da Rede a médio prazo, segundo a ITES, é preocupante, tendo a vista o desafio de sustentabilidade dos bancos. Apesar de não considerar que a rede esteja passando por um processo de enfraquecimento, a entrevistada reconhece que apenas uma parte dos bancos-membro tem participado ativamente, enquanto outros estão menos interessados, causando um desequilíbrio na rede. Recentemente, a ITES desenvolveu um momento de sensibilização com os bancos sobre os possíveis rumos da rede, caso não haja uma mobilização para captação de recursos visando novos projetos. Por outro lado, a técnica enxerga que do ano de 2014 até hoje a rede tem se fortalecido no quesito comunicação, o que julga como positivo.

Quando questionada sobre os desafios e dificuldades da Rede, a entrevistada comenta a questão das entidades gestoras dos bancos: ou nasceram frágeis ou se fragilizaram ao longo do processo, deixando de captar recursos para seu próprio sustento. A ITES, por vezes, também não conseguiu acompanhar de perto todos os bancos. Uma das grandes dificuldades são as relações com as próprias entidades gestoras dos bancos e suas relações na comunidade com outros atores da economia solidária.

Bancos que conseguem uma sustentabilidade não ficam tão dependentes da rede quanto bancos que não conseguem outras ferramentas para sua própria sustentabilidade. A locomoção também é um fator preponderante de desafio/dificuldade na rede: os recursos não são suficientes para trazer todos os participantes, e ainda quando isso é possível, a entrevistada acredita que falta o sentimento de se sentir parte da rede por parte de alguns membros. Não são 
poucas as vezes que marcam reuniões com um mês de antecedência e em cima da hora agentes não comparecem. A entrevistada comenta que recebeu um retorno de uma das agentes de crédito de que não participa das reuniões pelo fato de eu o seu banco está fragilizado, e que não teria com o que contribuir na reunião.

“Existem dificuldades que são práticas, por exemplo, a gente marca reunião com um mês de antecedência, chega na hora: 'ah, eu tenho médico, não posso ir'. Aí já é comprometimento, né? Se você marcou, cumpra. Aí já entra o quanto eles se sentem parte da rede (...) existem essas dificuldades de ordem prática, que contam, mas que não são maiores".

Quanto aos benefícios gerados pela rede, a técnica afirma que não enxerga benefícios apenas para os bancos, mas para as finanças e economia solidária em geral. Tudo o que se constrói dentro da rede é revertido em benefício para os bancos, para os agentes, para os atores envolvidos e toda a comunidade. Nesse contexto, a entrevistada comenta que a rede propicia para os bancos-membros informações políticas, conscientização da necessidade de articulação, sentimento de pertencimento a um grupo, bolsas auxilio liberadas pelas entidades de fomento, além de angariar recursos que são revertidos em benefícios para a própria rede, como cursos, oficinas, encontros, visitas e intercâmbios.

“O benefício não é diretamente 'pro' banco, mas pro movimento de finanças e economia solidária (...) a rede traz um benefícios que articulação política, o benefício de pertencimento a um grupo. Hoje as pessoas estão mais engajadas, interessadas pela Rede Baiana, quer que ela se perpetue (...) a gente fez uma oficina de excel, é benefício 'pros' bancos, né? (...) os bancos da Rede Baiana puderam participar do último curso de correspondente bancário (...) e tem os benefícios também indiretos, capacitação, participação, intercâmbios (...) Agrega para o banco conhecer outras realidades".

A entrevistada ainda comenta que muitas vezes o único interesse de algumas pessoas envolvidas na rede são os encontros, viagens 
que são proporcionadas, mas não estão de fato comprometidas com a responsabilidade de representar o banco ou a rede. Algumas assimetrias no comportamento da Rede Baiana têm comprometido o seu andamento, mas de acordo com a ITES, ainda não chega a ser um fator crítico de insucesso.

Quadro 3: Resumo dos resultados - ITES

\begin{tabular}{|c|c|c|}
\hline Categorias & Elementos de análise & Resultados \\
\hline \multirow[t]{2}{*}{$\begin{array}{l}\text { Organização } \\
\text { da rede de } \\
\text { economia } \\
\text { solidária }\end{array}$} & $\begin{array}{l}\text { Percepção sobre a } \\
\text { organização da Rede } \\
\text { Baiana }\end{array}$ & $\begin{array}{l}\text { Todos os membros possuem } \\
\text { mesmo poder de voto; } \\
\text { Participação igualitária; } \\
\text { A ITES como principal conduto- } \\
\text { ra dos processos. }\end{array}$ \\
\hline & Importância da rede & $\begin{array}{l}\text { Fortalecimento das finanças soli- } \\
\text { dárias de forma geral. }\end{array}$ \\
\hline $\begin{array}{l}\text { Benefícios da } \\
\text { Rede }\end{array}$ & $\begin{array}{l}\text { Benefícios alcançados } \\
\text { pela Rede Baiana }\end{array}$ & $\begin{array}{l}\text { Informações políticas; } \\
\text { Conscientização da necessidade } \\
\text { de articulação; } \\
\text { Sentimento de pertencimento a } \\
\text { um grupo; } \\
\text { Participação em cursos, encon- } \\
\text { tros, intercâmbios e visitas. }\end{array}$ \\
\hline \multirow{2}{*}{$\begin{array}{l}\text { Percepções } \\
\text { sobre a Rede } \\
\text { Baiana }\end{array}$} & $\begin{array}{l}\text { Situação atual da Rede } \\
\text { Baiana }\end{array}$ & Fortalecida. \\
\hline & $\begin{array}{l}\text { Desafios e dificulda- } \\
\text { des }\end{array}$ & $\begin{array}{l}\text { Fragilidade das entidades gesto- } \\
\text { ras; } \\
\text { Sustentabilidade e fragilidade } \\
\text { dos BCDs; } \\
\text { Deslocamento para participar } \\
\text { das ações da Rede; } \\
\text { Sentimento de pertencer a Rede. }\end{array}$ \\
\hline
\end{tabular}

Fonte: elaborado pelos autores.

\subsubsection{Banco Comunitário ILHAMAR}

O banco comunitário ILHAMAR foi o segundo banco inaugurado na Bahia. Localizado na comunidade de Matarandiba, uma vila de pescadores que fica a 33 quilômetros da sede do município, a cidade de Vera Cruz. O Banco ILHAMAR foi fundado em abril de 2008 com 
a missão de "interagir a comunidade socioeconomicamente, através do oferecimento de microcrédito solidário, para gerar produção, consumo e serviços, criando oportunidades de trabalho e renda" (Projeto Ecosmar, 2008, p.21). Sua moeda social é a concha em referência a economia local do lugar. O banco oferece 4 linhas de crédito: crédito para consumo, em moeda social; crédito para pequenas reformas; crédito para produção; e crédito para jovens da comunidade que queiram iniciar um pequeno negócio. Ele foi um dos fundadores da Rede Baiana de BCDs onde participa ativamente de suas atividades.

O Banco Ilhamar integra a Rede Baiana desde o seu início, em 2010. Para o Banco Ilhamar, a Rede é de fundamental importância, tendo em vista que proporciona a integração entre bancos, a comunicação, a troca de informações e principalmente o compartilhamento de dificuldades enfrentadas pelos bancos. Segundo a agente de crédito, não são raras as vezes em que, em reuniões, os bancos compartilham suas dificuldades e são aparados por outros bancos que já estiveram na mesma situação e lhes sugerem meios de enfrentar a crise.

"Cada comunidade tem suas dificuldades. O que uma comunidade enfrenta, outra já não enfrenta, então a gente troca essas experiências, e o que eu enfrentei aqui, outra comunidade já superou... e como ela fez 'pra' superar? Então a gente troca essas experiências. Também como equipe é importante para levantar recursos também".

Além disso, a rede tem proporcionado o fortalecimento das equipes, auxiliando no angariamento de recursos para tocar os projetos; auxiliado na reabertura de bancos enfraquecidos e na formação de equipes que irão atuar na comunidade.

Sobre o funcionamento da Rede, a agente de crédito informou que não existe uma coordenação, e que, na prática, quando sai um edital eles procuram a associação do banco que está mais fortalecido para concorrer ao edital.

Quanto aos benefícios conquistados pelos bancos por meio da Rede, a agente de crédito informou que a Rede auxiliou no fortalecimento, devido ao fomento da comunicação entre os bancos, gerando uma ajuda mútua entre eles. A exemplo disso, citou um 
banco que estava passando por problemas gerais e que um outro banco da Rede auxiliou na reabertura do banco. "Acho que esse é o benefício da Rede: um está olhando pro interesse do outro. Um está querendo ajudar o outro".

Além disso, a agente conta os benefícios individuais que a Rede gerou aos bancos: o Banco Ilhamar conta com a ajuda da Rede no dia-a-dia, em relação à organização, gestão, resolução de problemas e motivação de equipes.

A agente cita que a participação na Rede abriu muitas portas, como por exemplo de cursos, como o de correspondente bancário, participação de grupos de trabalho e intercâmbios com outras instituições. Para ela, são experiências pessoais e profissionais que geraram um desenvolvimento pessoal imenso, e que só foi possível por meio da participação na Rede. Ela cita ainda que sente diferença em trabalhar com a Rede e trabalhar como um banco isolado, principalmente no tocante à tomada de decisão. Várias decisões mais sólidas e conscientes são tomadas a partir da análise das informações obtidas em grupos de discussão promovidos pela rede.

No tocante às dificuldades enfrentadas pela Rede, a percepção da entrevistada é de que a o principal problema está na desmotivação das equipes, principalmente em relação às reuniões. A falta de compromisso em participar das reuniões, oficinas e eventos proporcionados tem gerado um enfraquecimento da Rede, em sua opinião.

"As dificuldades que a gente encontra hoje são as pessoas mesmo. As pessoas estão desanimadas mesmo, porque antes a gente não tinha recursos, e hoje que tem a gente marca um encontro e as pessoas ficam dizendo que não dá. A gente desmarca e quando marca novamente as mesmas pessoas dizem que não podem. Então a gente tá encontrando dificuldades com os membros. (...) quando a gente faz as oficinas, os encontros, a gente sempre fala da importância de se reunir.

A agente relembra que antes havia uma motivação por parte dos bancos em busca de interesses gerais, mas que a Rede não possuía recursos. Hoje, a Rede tem obtido recursos por meio de editais, mas não existe a mesma motivação por parte dos membros. Apenas três bancos ainda estão motivados, além dos novos, que estão 
começando agora e é natural essa motivação. Para entrevistada, a rede está mais fragilizada. A entrevistada acredita que se a Rede acabasse, a situação dos bancos que estão fragilizados estaria ainda pior, chegando a fechar as portas. Mesmo frágil, em sua opinião, a rede baiana ainda é de suma importância para os BCDs da Bahia.

Quadro 4: Resumo dos resultados - Banco ILHAMAR

\begin{tabular}{|l|l|l|}
\hline Categorias & $\begin{array}{l}\text { Elementos de } \\
\text { análise }\end{array}$ & Resultados \\
\hline $\begin{array}{l}\text { Organização da } \\
\text { rede de econo- } \\
\text { mia solidária }\end{array}$ & $\begin{array}{l}\text { Percepção sobre } \\
\text { a organização da } \\
\text { Rede Baiana }\end{array}$ & Não existe uma coordenação. \\
\cline { 2 - 4 } & $\begin{array}{l}\text { Importância da } \\
\text { Rede Baiana }\end{array}$ & $\begin{array}{l}\text { Proporciona interação entre os } \\
\text { bancos; } \\
\text { Troca de informações. }\end{array}$ \\
\hline $\begin{array}{l}\text { Benefícios da } \\
\text { Rede }\end{array}$ & $\begin{array}{l}\text { Benefícios alcança- } \\
\text { dos pela Rede }\end{array}$ & $\begin{array}{l}\text { Auxilia na reabertura dos bancos; } \\
\text { Formação; } \\
\text { Capitação de recursos; } \\
\text { Fortalece os BCDs participantes; } \\
\text { Desenvolvimento pessoal; } \\
\text { Abre portas; } \\
\text { Auxilia nas ações do dia-a-dia do } \\
\text { banco; } \\
\text { Integras os bancos; } \\
\text { Melhoria na Comunicação; } \\
\text { Possibilita a troca de informações. }\end{array}$ \\
\hline $\begin{array}{l}\text { Percepção } \\
\text { Baiana }\end{array}$ & \begin{tabular}{l} 
Situação atual da \\
Rede Baiana \\
\cline { 2 - 4 } Desafios e dificul- \\
dades
\end{tabular} & $\begin{array}{l}\text { Fragilizada. } \\
\text { Enfraquecimento da rede devido à } \\
\text { baixa participação. }\end{array}$ \\
\hline
\end{tabular}

Fonte: elaborado pelos autores.

\subsubsection{Banco Comunitário Casa do Sol}

O terceiro banco da Bahia está sediado na comunidade de Cairu-sede, na cidade de Cairu. O Banco Casa do Sol foi inaugurado em setembro de 2009 fruto da demanda da comunidade à compensação da PETROBRÀS pela extração de gás natural no campo de 
Manati, localizado em frente aos distritos de Garapuá e Morro de São Paulo (Bahia). O banco oferece duas linhas de crédito, uma em moeda social (Tinharé) e outra em real, o crédito para produção que subdividisse em Credpesca e Credalternativo. O banco Casa do Sol, hoje, apresenta estrutura de gestão formada por uma agentes de crédito de crédito, um conselho gestor, assim como um CAC (Comitê de Avaliação de Crédito).

O Banco Casa do Sol tem passado por uma série de dificuldades em manter suas atividades funcionando plenamente. Pode-se considerar que nos anos subsequentes da sua inauguração, em 2009, o banco teve uma atuação exemplar, inclusive para a Rede baiana de Bancos Comunitários, uma vez que contava com uma ampla aceitação da moeda social, possuía um corpo técnico de quatro agentes de crédito de crédito, um conselho gestor atuante, assim como CAC (Comitê de Avaliação de Crédito). Mas ao longo dos anos, em especial a partir do ano de 2012, o banco tem passado por algumas perdas; inicialmente o corpo de agentes de créditos reduziu-se para apenas 1 agente de crédito, a antiga sede do banco (cedido pela prefeitura) precisou ser retomado, obrigando o banco a funcionar em um casarão abandonado e de difícil acesso.

Esse contexto provocou uma maior desarticulação do processo de mobilização, circulação da moeda local e mesmo quantidade de empréstimos. Um dos resultados do processo de fragilização do banco foi o aumento do número de inadimplentes e consequente redução do fundo de recursos para empréstimos. O banco praticamente parou suas atividades em 2014 realizando apenas algumas ações e só não paralisou totalmente suas atividades graças a uma articulação com o poder público, que garantiu a contratação da agente

A agente de crédito também se queixou da ausência de apoio por parte da comunidade e principalmente da presidente da associação responsável por abrigar o banco, que durante o período de 2014 não quiseram se envolver no processo de restruturação do banco.

"Eu fiquei praticamente sozinha a frente do banco, tentei marcar várias reuniões com a comunidade e ninguém aparecia. A presidente da associação não apareceu se quer uma vez durante todo o ano, praticamente abandou o banco". 
Mesmo com toda dificuldade o banco continuou ativo e a agente de crédito mantem-se participando das reuniões de bancos comunitários; seja participando de encontros da rede baiana de bancos e da rede brasileira de bancos comunitários. Aliais foi graças a rede baiana que o banco está se recuperando. A rede realizou duas vistas ao banco entre 2014 e 2015, além de ter organizado um encontro da rede em Cairu, onde foram realizadas uma série de atividades de formação, avaliação da situação atual do banco, mobilização com a comunidade e visita aos comerciantes.

“Eu sempre que posso vou as reuniões, nós fazemos parte da rede desde de 2010, desde que ela foi fundada...o pessoal da rede veio duas vezes aqui para tentarmos recuperar, foi feito aqui um encontro da rede e em janeiro de 2017 iremos voltar a emprestar".

Entre as ações realizadas pela rede houve uma avaliação da situação do banco com os membros do conselho gestor, em que ficou definida a necessidade de altera-se o local da sede do banco, bem como da sua entidade gestora. $\mathrm{O}$ banco passou a ser gerido pelo Sindicato municipal das Marisqueiras. Essa mudança tem sido fundamental na retomada das ações do banco.

A entrevistada falou também sobre a forma como a rede é gerida. Segundo ela há uma coordenação composta por um membro de cada banco, mas que todos que estão participando das reuniões dão opinião independentemente de serem o representante ou não. Ela também ressaltou a importância da rede e do companheirismo e solidariedade que há entre os seus membro.

"A rede baiana é muito importante para os bancos, quando um tem um problema nós que somos as agentes de créditos tentamos um ajudar o outro, quando tem um problema todos se juntam para ir apoiar o outro, tentando resolver o problema".

Outro ponto destacado foram os benefícios que a rede tem proporcionado aos bancos. A rede tem proporcionado encontros, intercâmbios, compartilhamento de informações, capacitação, tem ajudado na resolução de problemas e orientado na forma como as 
atividade são realizadas. Pessoalmente tem sido bom para a entrevistada participar da rede, ela ajudou no dia a dia das atividades no banco, ajudou a sua relação com as pessoas e a aumentou seu conhecimento.

“Os benefícios são vários, a gente vai ter mais conhecimento, se tem um problema aqui eu peço informação das meninas tentando resolver ... vejo como elas fazem nos outros bancos para eu fazer aqui...para mim é sempre um conhecimento novo, sempre que a gente viaja pelos banco, faz intercâmbio, tem sempre informação nova".

A preocupação com o enfraquecimento e os desafios enfrentados pela rede, também estiveram presentes na fala da entrevistada. Segundo ela, as pessoas não estão demostrando interessem em se envolver com as atividades da rede, não há mais o mesmo interesse que existia quando a rede foi formada, onde todos participavam, davam opinião e tinham disponibilidade para se envolver com as atividade. Ela também demostrou preocupação com o problema do deslocamento para participar das atividades da rede, que para a entrevistada é, hoje, o maior desafio da rede.

"Eu, no geral, estou achando que as pessoas estão mais desinteressadas, porque eu vejo as meninas tentando fazer uma reunião e não deu certo isso enfraquece a rede(...) também tem o problema do deslocamento, a maioria são mulheres e fica difícil ficar três dias fora. Eu mesmo, tenho marido e filhos, para ir para uma reunião tenho que sair um dia antes e voltar um dia depois e nem sempre dá 'pra' ir".

Segundo a agente de crédito entrevistada, existe uma preocupação com a continuidade da rede. $\mathrm{O}$ fim da rede seria uma perda significativa para os bancos que tem se beneficiado com a troca de experiências, com os momentos de intercâmbio, com a capitação de recursos e articulação com outras entidades de apoio.

"A rede tem que continuar, a rede baiana é muito importante para os bancos comunitários, mas agora para rede funcionar todos os bancos tem que participar. Se as pessoas não voltarem a se envolver na rede 
e ela acabar vai ser horrível, vai prejudicar os bancos. Com a rede tem como se reunir, fazer projetos, conversar com outras pessoas de outros bancos e sem a rede isso tudo acaba".

Quadro 5: Resumo dos resultados - Banco Casa do Sol

\begin{tabular}{|l|l|l|}
\hline Categorias & Elementos de análise & Resultados \\
\hline $\begin{array}{l}\text { Organização da } \\
\text { rede de econo- } \\
\text { mia solidária }\end{array}$ & $\begin{array}{l}\text { Percepção sobre a orga- } \\
\text { nização da Rede Baiana }\end{array}$ & $\begin{array}{l}\text { Composta por um membro } \\
\text { de cada BCD. }\end{array}$ \\
\cline { 2 - 3 } & $\begin{array}{l}\text { Importância da Rede } \\
\text { Baiana }\end{array}$ & $\begin{array}{l}\text { Estimulo ao Companheirismo } \\
\text { e a solidariedade. }\end{array}$ \\
\hline $\begin{array}{l}\text { Benefícios da } \\
\text { Rede }\end{array}$ & $\begin{array}{l}\text { Benefícios alcança- } \\
\text { dos pela Rede }\end{array}$ & $\begin{array}{l}\text { Participação em encontros e } \\
\text { intercâmbios; } \\
\text { Compartilhamento de infor- } \\
\text { mações; } \\
\text { Capacitações; } \\
\text { Resolução de problemas; } \\
\text { Capitação de recursos. }\end{array}$ \\
\hline $\begin{array}{l}\text { Percepção sobre } \\
\text { a Rede Baiana }\end{array}$ & $\begin{array}{l}\text { Situação atual da Rede } \\
\text { Baiana }\end{array}$ & \begin{tabular}{l} 
Fragilizada. \\
\cline { 2 - 3 }
\end{tabular} \\
$\begin{array}{l}\text { Desafios e dificul- } \\
\text { dades }\end{array}$ & $\begin{array}{l}\text { Deslocamento dos participan- } \\
\text { tes; } \\
\text { Desinteresse em envolve-se } \\
\text { com as atividades da rede. }\end{array}$ \\
\hline
\end{tabular}

Fonte: elaborado pelos autores.

\subsubsection{Banco Solidário Quilombola do Iguape}

O Banco Solidário Quilombola do Iguape foi inaugurado em 20 de novembro de 2013 e atua com uma linha de crédito em moeda social circulante chamada Sururu e outra para produção, em real. O banco foi projetado pelas comunidades para apoiar os núcleos produtivos empreendimentos em suas atividades e estratégias de comercialização. Sua área de atuação abrange as comunidades quilombolas do entorno da Bacia e Vale do Iguape: Kaonge, Kalembá, Dendê, Engenho da Ponte Engenho da Praia, Engenho da Cruz, Engenho novo, Kalolé, Imbiara e Santiago do Iguape. Desde a sua fundação, o banco faz parte de Rede Baiana de Bancos Comunitários de Desenvolvimento. 
Segundo as agentes de crédito do banco que foram entrevistados nesse estudo, a rede é um entrelace entre teoria e prática. A incubadora da Universidade da Bahia tem contribuído com o suporte acadêmico necessário para o andamento da rede, e os agentes dos bancos tem contribuído com a prática diária, não existindo apenas uma pessoa que tome a frente e organize a rede de forma individual. Os agentes afirmaram que existe uma estrutura igualitária dentro da rede, em que as decisões são tomadas por meio de um consenso.

“Tudo que é decidido é no consenso com a rede em geral (...) no evento, por exemplo, é decido a data, onde vai ser o próximo, e posteriormente a gente joga a data na rede para ver se realmente todo mundo vai poder vir, e se não puderem vir, vai ter que mudar, mas é tudo no consenso, a decisão é coletiva. Todo mundo acompanha tudo".

Para o banco, a Rede Baiana tem sido de fundamental importância na promoção de intercâmbios, visitações, troca de informações, de forma que tem proporcionado experiências pessoais e profissionais aos membros da rede. De acordo com as entrevistadas, a rede funciona de fato. As mensagens postadas nos grupos (rede sociais) são levadas a sério e há uma interação entre os participantes. Além disso, a rede tem auxiliado na divulgação dos bancos, de forma a trazer uma melhor visibilidade para a economia solidária no estado da Bahia, trazendo novos clientes. Outrossim, a divulgação foi citada como maior contribuição no sentido de fortalecimento dos bancos, pois por meio dela, os bancos têm adquirido visibilidade.

Entre os benefícios de fazer parte da rede, as agentes destacam que o apoio dos técnicos da ITES é um dos principais pontos a serem destacados. Por meio desse apoio, o banco recebe orientação técnica, sugestões, dicas, e tiram dúvidas existentes. Além disso, outro ponto destacado é a capacitação dos agentes e a divulgação do próprio banco, por meio da rede.

Em contrapartida, uma das entrevistadas afirmou que existem vantagens e desvantagens em participar da rede. Tendo em vista as vantagens já citadas, as desvantagens mais comuns giram em torno de tentar manter o equilíbrio entre todos os membros da rede, uma vez que é necessário alinhar os discursos, pensamentos, para que 
se chegue a um consenso. Esse cenário, afirma a agente, gera um nível de estresse.

O banco se considera bastante engajado dentro da rede, participando dos eventos, mesmo quando a rede não tem condições de custear a sua ida. Quando questionadas sobre o que a rede tem feito pelos bancos comunitários participantes, as entrevistadas lembram de situações como a abertura e reabertura de bancos, capacitação de seus agentes e incentivo aos bancos para a captação de recursos em editais.

“Desse período, eu já vi a rede inaugurar alguns bancos, dois ou foram três, se não me engano (...) o pessoal está fazendo capacitação com as agentes, então eu acho que a rede tem feito seu papel com frequência... de capacitação, de incentivar a rede a correr atrás de recursos para os bancos, então tem incentivado muito, principalmente na parte financeira e de capacitar pessoal".

Sobre as dificuldades e desafios da Rede Baiana hoje, foi identificado como maior problema a falta de compromisso dos membros em comparecer a eventos e reuniões. As entrevistadas comentam que houve situações em que a rede teve despesas com hospedagem, transporte, alimentação, mas os agentes dos bancos não compareceram. Segundo uma das entrevistadas, o que falta é o sentimento de fazer parte, vestir a camisa da rede.

Para outra agente, essa dificuldade é decorrente da falta conscientização da responsabilidade dos bancos sobre os projetos que a rede está engajada para auxiliar os próprios bancos. A rede arrecada fundos para que os próprios bancos possam crescer e se fortalecer, e os bancos tem deixado a desejar, tendo esses recursos em mãos.

Quando questionadas sobre a fragilidade da rede, as entrevistadas tiveram visões diferentes sobre o assunto. Enquanto uma das agentes acredita que a rede está mais fragilizada, devido à falta de compromisso dos membros, a falta de posicionamento, de participação e de ação, a outra agente acredita que existe todas essas nuances, mas não considera que isso seja o suficiente para o diagnóstico de enfraquecimento, acreditando que se o problema pode ser resolvido com mais reponsabilidade por meio dos membros. 
Também foi citado que a mudança recente de governo complicou a ação dos bancos, pois o governo que assumiu tem uma postura de direita, e a percepção das agentes é de que eles são totalmente contra o trabalho. Acreditam ainda que a rede é essencial para o fortalecimento dos bancos, e que é necessário que haja um despertamento maior com os próprios membros sobre a importância da rede, para que os bancos continuem sendo beneficiados.

Quadro 6: Resumo dos resultados - Banco Quilombola do Iguape.

\begin{tabular}{|c|c|c|}
\hline Categorias & $\begin{array}{l}\text { Elementos de } \\
\text { análise }\end{array}$ & Resultados \\
\hline \multirow[t]{2}{*}{$\begin{array}{l}\text { Organização da } \\
\text { rede de economia } \\
\text { solidária }\end{array}$} & $\begin{array}{l}\text { Percepção sobre a } \\
\text { organização da Rede } \\
\text { Baiana }\end{array}$ & $\begin{array}{l}\text { Misto de teoria e prática; } \\
\text { Estrutura igualitária; } \\
\text { As decisões são tomadas por } \\
\text { meio do consenso. }\end{array}$ \\
\hline & $\begin{array}{l}\text { Importância da } \\
\text { Rede Baiana }\end{array}$ & $\begin{array}{l}\text { Promoção de intercâmbios; } \\
\text { Troca de informações. }\end{array}$ \\
\hline Benefícios da Rede & $\begin{array}{l}\text { Benefícios alcan- } \\
\text { çados pela Rede } \\
\text { Baiana }\end{array}$ & $\begin{array}{l}\text { Promoção de intercâmbios; } \\
\text { Visitações; } \\
\text { Troca de experiência e infor- } \\
\text { mações; } \\
\text { Divulgação dos BCDs; } \\
\text { Capacitação de agentes; } \\
\text { Apoio técnico. }\end{array}$ \\
\hline \multirow[t]{2}{*}{$\begin{array}{l}\text { Percepção sobre a } \\
\text { Rede Baiana }\end{array}$} & $\begin{array}{l}\text { Situação atual da } \\
\text { Rede Baiana }\end{array}$ & $\begin{array}{l}\text { Fragilizada (entrevistada 1); } \\
\text { Embora esteja passando por } \\
\text { dificuldades encontra-se forta- } \\
\text { lecida (entrevistada 2). }\end{array}$ \\
\hline & $\begin{array}{l}\text { Desafios e difi- } \\
\text { culdades }\end{array}$ & $\begin{array}{l}\text { Manter o equilíbrio entre os } \\
\text { membros da rede; } \\
\text { Falta de compromisso em par- } \\
\text { ticipar das reuniões e eventos; } \\
\text { Falta de sentimento de perten- } \\
\text { cimento da rede; }\end{array}$ \\
\hline
\end{tabular}

Fonte: elaborado pelos autores. 


\subsubsection{Banco Comunitário Abrantes Solidário}

O Banco Comunitário Abrantes Solidário foi inaugurado em novembro de 2014 e é um dos últimos bancos criados na Bahia, e o primeiro localizado no litoral Norte baiano. Sua sede fica na comunidade de Vila do Abrantes na cidade de Camaçari. A moeda se chama Abrantes e o banco oferece duas linhas de crédito, uma para consumo em moeda social e outra para produção. Além dos empréstimos, o banco realiza assistência técnica, cursos de capacitações e a construção de planos de gestão para os empreendimentos que tomam crédito no banco.

Pertencente a rede baiana desde de 2014 o banco tem participado de todas as atividades realizadas desde então. Para o BCD a rede baiana é coordenada pela ITES, que foi a responsável pela criação da rede de bancos, além de ser a entidade que fomenta a criação de bancos comunitários na Bahia e outros estados do Nordeste. Segundo a agente de crédito do banco é a incubadora que é responsável pela capitação de recursos por meio de projetos, para que seja realizados os intercâmbios, as reuniões, os encontros e as capacitações. A exceção foi o último edital capitaneado conjuntamente com os demais membros da rede. Ela ressalta, que embora a rede seja coordenada pela ITES as decisões em torno das atividades que serão realizadas pela rede são decididas por todos os membros.

“A coordenação é composta pela pessoal da incubadora. Através deles é que são capitados projetos e desses projetos começamos a nos articular fazendo intercâmbio, reuniões e visitas aos outros bancos...nessas reuniões nós decidimos quais atividades iremos realizar, quais são os passos que a rede vai dar, a decisão é de todos da rede".

Questionada sobre a importância da rede baiana, a entrevistada argumentou que tem sido importante, tanto para o crescimento pessoal dos participantes, como para o fortalecimento das instituições que dela fazem parte, no caso os bancos comunitários e a incubadora. Os bancos de maneira geral vem sendo fortalecidos através das ações realizadas pela rede, como as capacitações, os intercâmbios, a participação em eventos, a realização de atividade em conjunto e principalmente pela troca de experiência e pelo 
apoio aos bancos mais fragilizados, através das visitas em loco. No âmbito pessoal o crescimento tem sido proporcionado pelas trocas de experiência e pelas capacitações realizadas. Umas das capacitações, conforme relatada pela entrevistada, vem permitindo o fortalecimento dos bancos, como da própria rede, por meio da capitação de recursos.

Em relação aos benéficos proporcionados pela rede destacam-se: o aprendizado, a ajuda mutua entre os bancos, o crescimento profissional e a ajuda no desenvolvimento das comunidades. Segundo a agente de crédito entrevistada, a rede tem proporcionado variados momentos de aprendizado, seja nas formações, seja nos vários espaços de articulação política e/ou na participação em encontros e eventos de economia solidária e finanças solidárias. A troca de experiência e o apoio dado entre elas tem fortalecido e ajudado no dia a dia das atividades do banco. Essa troca de experiência somada a capitação de recursos e a demais atividades tem permitido a ampliação das ações dos bancos em seus territórios contribuindo para o desenvolvimento das localidade onde atuam os BCDs, principalmente com a ampliação da oferta de crédito.

"Pra mim o aprendizado com os projetos sócias é grande. Ajudar as comunidades, ajudar uns aos outros, faz a gente crescer e isso tem sido um grande benefício. A rede baiana e os bancos têm ajudado as comunidades carentes(...) através desses projetos as comunidades têm crescido, muitas famílias têm sido apoiadas".

Quanto a situação atual da rede, segundo o Banco, ela encontra-se fortalecida. Na visão da entrevistada o sentido da rede é proporcionar os intercâmbios entre os participantes e contribuir com o fortalecimento dos bancos atuais, além de fomentar a expansão da experiências entre outros territórios da Bahia. A rede tem proporcionado geração de renda, tem permitido que os atores se encontrem, tem contribuído na recuperação dos bancos que estão mais fragilizados, tem garantido o deslocamento das agentes para outros territórios, para realizarem oficinas, realizarem formação junto as associações e realizarem mobilização nas comunidades. Também tem contribuído para criação de novos bancos, além de 
fomentar a articulação com instituições públicas como prefeituras e o governo do estado.

“Eu acho que ela está mais fortalecida, ela tem dado oportunidades que sem ela não existiriam. A rede existe para que esses bancos possam se encontrar, e é isso que faz a rede, então se a gente não tivesse a oportunidade de estar se encontrando, de estar trocando ideias, levando experiências uns para os outros, talvez alguns bancos não existissem mais".

No que se refere aos desafios enfrentados pela rede foram identificados três desafios principais. $\mathrm{O}$ primeiro está relacionado com atual cenário político e econômico que tem reduzido os recursos disponíveis resultando na redução de atividades da rede, principalmente as visitas para os bancos mais fragilizados e os novos bancos. O segundo desafio está relacionado a participação nas atividades desenvolvidas pela rede, pois boa parte dos bancos possuem apenas uma agente de crédito e sua participação nas reuniões, intercâmbios, eventos e vistas implicaria no fechamento do banco no período da atividade, o que leva a muitos deixarem de participar. O terceiro e último desafio está no processo auto gestionário da rede, que segundo a agente dificulta a tomada de decisão, pois precisa do consenso entre a maioria o que leva a uma demora maior na decisão final.

A importância da continuidade da rede baiana também foi expressa pela entrevistada na finalização de sua fala.

"A rede baiana existe por causa dos bancos comunitários, então um é a fortaleza do outro, se um lado cair o outro cai. A rede baiana como um todo tem que continuar, ela fortalece os bancos comunitários". 
Quadro 7: Resumo dos resultados - Banco Solidário do Abrantes

\begin{tabular}{|c|c|c|}
\hline Categorias & Elementos de análise & Resultados \\
\hline \multirow[t]{2}{*}{$\begin{array}{l}\text { Organização da } \\
\text { rede de econo- } \\
\text { mia solidária }\end{array}$} & $\begin{array}{l}\text { Percepção sobre a for- } \\
\text { ma de organização da } \\
\text { Rede Baiana }\end{array}$ & $\begin{array}{l}\text { Coordenada pela ITES; } \\
\text { Decisões são coletivas. }\end{array}$ \\
\hline & $\begin{array}{l}\text { Importância da Rede } \\
\text { Baiana }\end{array}$ & $\begin{array}{l}\text { Crescimento pessoal dos parti- } \\
\text { cipantes; } \\
\text { Fortalecimento das instituições. }\end{array}$ \\
\hline $\begin{array}{l}\text { Benefícios da } \\
\text { Rede }\end{array}$ & $\begin{array}{l}\text { Benefícios alcança- } \\
\text { dos pela Rede Baiana }\end{array}$ & $\begin{array}{l}\text { Fortalecimento das organiza- } \\
\text { ções; } \\
\text { Aprendizagem; } \\
\text { Crescimento profissional; } \\
\text { Ajuda no desenvolvimento das } \\
\text { comunidades. }\end{array}$ \\
\hline \multirow[t]{2}{*}{$\begin{array}{l}\text { Percepção sobre } \\
\text { a Rede Baiana }\end{array}$} & $\begin{array}{l}\text { Situação atual da Rede } \\
\text { Baiana }\end{array}$ & Fortalecida. \\
\hline & $\begin{array}{l}\text { Desafios e dificul- } \\
\text { dades }\end{array}$ & $\begin{array}{l}\text { Cenário político e econômico; } \\
\text { Estrutura fragilizada de alguns } \\
\text { bancos; } \\
\text { Trabalho auto gestonário. }\end{array}$ \\
\hline
\end{tabular}

Fonte: elaborado pelos autores.

\subsubsection{Banco da Associação Mãe dos Extrativistas da Resex de Canavieiras - BAMEX}

Inaugurado em dezembro de 2012, o Banco Comunitário de Desenvolvimento - BAMEX foi construído em parceria de técnicos da Universidade Federal da Bahia com 14 associações que compõem a Associação Mãe dos Extrativistas da Resex de canavieiras - AMEX. Os serviços financeiros prestados pelo banco comunitário são de natureza associativa e solidária e tem por base ações de financiamento do consumo e produção em dois tipos de moeda: a moeda social denominada MOEX e o real. O banco oferece 4 linhas de crédito: crédito para consumo liberado em MOEX; o crédito para Reforma e construção; o crédito para produção; e o crédito para pesca e mariscagem. 
O BAMEX ingressou na rede baiana de BCDs em 2012, mesmo ano de sua fundação, e hoje é um dos mais atuantes na rede. Sua agente de crédito destaca que a rede é formada e gerida por representantes de todos os bancos, além da incubadora, que além de ser membro da rede, também dar suporte técnico para os BCDs. A rede tem como meta se formalizar para que possa concorrer a editais como proponente.

"Na rede todo mundo se divide, a rede não tem identidade jurídica essa é uma das nossas metas, porque tem que ter uma entidade jurídica com todas as questões legais para que a gente concorra aos editais

Segundo o Banco BAMEX, a rede tem sido importante no fortalecimento dos BCDs. Ela tem contribuído na solução dos diversos problemas enfrentados pelos bancos em seus territórios. O trabalho coletivo dos BCDs tem fortalecido suas ações, o que não acontecia quando trabalhavam isolados em seus territórios. Esse trabalho coletivo de ajuda mutua é uma das principais conquista desta rede.

Além da importância da rede no fortalecimento dos bancos, ela tem proporcionado benefícios aos participantes da rede, principalmente no melhoria da comunicação em seus territórios e entre eles. A rede desenvolveu ações de mídia impressa e mídia eletrônica, que tem contribuído para tornar as ações e o próprio banco mais conhecido no território, dando-lhe mais visibilidade. Coletivamente foi desenvolvido um panfleto explicativo sobre os bancos, sobre a rede baiana e sobre os serviços prestado por essas organização, além de uma página de facebook, de um grupo no whatsapp e do site da rede, onde contém informações sobre os BCDs e ações que estão sendo desenvolvidas em rede. Segundo a entrevistada essas ações tem ajudado bastante para o fortalecimento da rede:

“Os folhetos explicativos ajudara muito na divulgação do banco, essas coisas ajudam a estimular o banco(...) Os grupos do facebook e whatsApp ajudam bastante, pois nós estamos espalhado em diversos lugares da Bahia e nem sempre podemos estar com o outro e com os grupos nós podemos nós falar e se ajudar todos os dias". 
A rede tem contribuído bastante na formação, autonomia e no empoderamento das suas trabalhadora(o)s para atuar nas atividades diárias do banco. Ela tem fortalecido a atuação do banco em seu território por meios das discussões sobre economia solidária, associativismos e finanças solidárias. Além disso a troca de experiência entre as agentes tem sido importante para superar o desafio de gerir o banco e resolver questões práticas do dia a dia.

"A rede me ajudou a ter mais autonomia para falar sobre o banco, você sabe falar mais, te empodera. Você consegue mostrar não só o seu banco, mas você consegue fazer as pessoas enxergarem além do banco sabe, você consegue abrir os olhos dela para a economia solidaria de uma forma geral".

Um ponto importante destacado na fala da agente foi a ampliação do número de parceiros proporcionados a partir das formações, discussões e orientações surgidas nas reuniões da rede de bancos sobre a importância da ampliação das parcerias para o fortalecimentos dos bancos nos territórios.

"A rede ajudou a gente a como se deve fazer para buscar o parceiro, ela deu mais empoderamento para a gente buscar, para expandir nossos parceiros, neste sentido assim ela ajudou bastante".

Outro ponto importante mencionado pela agente de crédito foi em relação ao fortalecimento da rede nos últimos anos e a sua capacidade de contribuir com a recuperação dos bancos que se encontram fragilizados. Antes cada banco agia por conta própria, hoje o problema de um banco é o problema de toda red. A rede também atuou diretamente na recuperação dos bancos Casa do Sol e Santa Luiza, ela tentou também a retomada das atividades do banco comunitário Saramandaia em Salvador, mas esse, ela não obteve sucesso e em rede foi decidido que este empreendimento não teria mais como funcionar como banco, mostrado maturidade na sua decisão.

Embora fortalecida nos últimos anos, o BAMEX demostra preocupação na continuidade das atividades da rede. Isso está ligado a dois motivos principais. O primeiro diz respeito ao atual cenário 
político e econômico do país, que tem impactado diretamente as fontes financiadoras de projetos sociais e com o fim do atual projeto da rede há a preocupação de como a rede irá se organizar para continuar realizando os encontros, os intercâmbios, as reuniões, as visitas e as demais atividades realizadas pela rede. "Hoje, devido a esse cenário político e econômico, a maior dificuldade é a gente buscar meios para se encontrar fisicamente, ter os nossos encontros".

O segunda motivo está ligada a pouca participação dos representantes dos bancos nos eventos promovido pela rede. Segundo a entrevistado isso não é fruto do desinteresse dos participantes e sim devido a agenda de compromissos, pois cada banco está abrigado juridicamente por uma associação e está tem sua própria agenda de reuniões, o que muitas vezes vem a se chocar com a agenda de atividades da rede. Conciliar as agendas de todos tem sido difícil.

"Cada BCDS tem as vezes uma agenda e as vezes as agentes tem uma agenda em cima de outra agenda. Mas essas questões quando nós encontramos vamos discutir em rede, mas que elas existem, elas existem, não tem como negar e tem que ser resolvida".

Apesar das dificuldades e da preocupação com a continuidade da rede, existe na fala da entrevistada um otimismo com a continuidade das ações impetradas pela rede no território onde o banco atua.

"Na cidade esse é o único empreendimento de economia solidária e enfrentamos uma grande dificuldade para convencer as pessoas a se envolverem. Eu joguei isso na rede, o pessoal já veio, já ajudou, já melhorou bastante, mas sempre vai precisar muito mais e tenho certeza que a rede a inda vai contribuir muito nesse processo".

\subsection{Análise dos dados}

De acordo com os dados gerados a partir das entrevistas e coleta de documentos, foi feita a análise do conteúdo.

\subsubsection{A gestão e organização da Rede Baiana}

Em relação a gestão da rede, foram obtidos documentos que mostram a sua estrutura de coordenação, tendo cada membro um representante. Todos os membros da rede confirmaram ela é disposta de maneira igualitária quanto a sua gestão, a decisão é tomada de forma conjunta e todos têm poder de voto e de mesmo peso. 
Quadro 8: Resumo dos resultados - Banco BAMEX.

\begin{tabular}{|l|l|l|}
\hline Categorias & $\begin{array}{l}\text { Elementos de aná- } \\
\text { lise }\end{array}$ & Resultados \\
\hline $\begin{array}{l}\text { Organização da } \\
\text { rede de economia } \\
\text { solidária }\end{array}$ & $\begin{array}{l}\text { Percepção sobre a } \\
\text { forma de or- } \\
\text { ganização da Rede } \\
\text { Baiana }\end{array}$ & $\begin{array}{l}\text { Gerida por representante de } \\
\text { todos os BCDs da rede. }\end{array}$ \\
\cline { 2 - 3 } & $\begin{array}{l}\text { Importância da } \\
\text { Rede Baiana }\end{array}$ & $\begin{array}{l}\text { Fortalecimentos dos BCDs atra- } \\
\text { vés do trabalho coletivo. }\end{array}$ \\
\hline $\begin{array}{l}\text { Benefícios da } \\
\text { Rede }\end{array}$ & $\begin{array}{l}\text { Benefícios al- } \\
\text { cançados pela Rede } \\
\text { Baiana }\end{array}$ & $\begin{array}{l}\text { Melhoria da comunicação; } \\
\text { Formações; } \\
\text { Autonomia e empoderamento } \\
\text { dos trabalhadores do BCD; } \\
\text { Ampliação de parcerias; } \\
\text { Recuperação de BCDs fragiliza- } \\
\text { dos; } \\
\text { Fortalecimento dos BCDs atra- } \\
\text { vés do trabalho coletivo. }\end{array}$ \\
\hline $\begin{array}{l}\text { Percepção sobre } \\
\text { a Rede Baiana }\end{array}$ & $\begin{array}{l}\text { Situação atual da } \\
\text { Rede Baiana }\end{array}$ & $\begin{array}{l}\text { Fortalecida, apesar dos desafios } \\
\text { enfrentados. }\end{array}$ \\
\cline { 2 - 4 } & $\begin{array}{l}\text { Desafios e difi- } \\
\text { Atual cenário político; } \\
\text { Pouco participação dos BCDs } \\
\text { nos eventos da rede. }\end{array}$ \\
\hline
\end{tabular}

Fonte: elaborado pelos autores.

Essa é uma das características de redes de cooperação encontrada na literatura, que segundo Macieirinha (2009), é formada por atores com objetivos em comum, com prazo indeterminado, que participam diretamente das decisões, beneficiando-se dos ganhos e benefícios igualitariamente. Apesar dessa afirmação, percebeu-se que existe uma certa condução da gestão por parte da ITES, a incubadora vinculada a Universidade Federal da Bahia; esse fato não é reflexo de uma imposição por parte da incubadora, mas da falta de um sentimento de empoderamento por parte dos bancos, fator fundamental em iniciativas sociais, como afirma França Filho (2010).

A maior parte bancos, mas não todos, ainda enxerga a ITES como a coordenadora do processo, talvez pelo fato de que ela tenha 
sido a fundadora da rede e detenha a "teoria", como citado pelo banco Quilombola do Iguapé. A própria incubadora, apesar de saber que tem tanto poder quanto o restante dos membros, entende que, de certa forma, é a condutora do processo, inclusive por experiências anteriores, em que se observou que quando se afastava do processo, a rede ficava parada; em outros casos, ainda, a incubadora precisou se responsabilizar por algumas ações, pois os membros se eximiram da responsabilidade. Apesar de haver uma gestão democrática, que segundo Gaiger (2009), constitui-se como um dos principais elementos da rede, os atores não estão em equilíbrio quanto a percepção da sua responsabilidade enquanto gestor da rede.

\subsubsection{A importância da Rede Baiana}

No tocante à importância da rede, é unânime que a rede tem auxiliado no fortalecimento dos bancos, proporcionando interação, comunicação, propagação de informações, capacitação, intercâmbios com outras instituições e auxilio técnico. A rede já fez a reabertura de bancos que estavam fechados e a capacitação de agentes para atuar em sua gestão.

É interessante notar um contraste no que diz respeito à percepção da importância da rede por parte dos bancos, mas ainda assim identificar a certa falta de responsabilidade e compromisso com a rede. Os bancos entendem o benefício que a rede tem atraído, principalmente no tocante a oportunidades de capacitação e intercâmbios e da visibilidade que a rede consegue proporcionar, mas ainda assim têm falhado no compromisso de estarem juntos em reuniões e eventos, discutindo o futuro da rede. Esse comportamento enfraquece os laços entre os atores, que passam a não sentir confiança mútua (GRANOVETTER, 1973; BRAZ; CARDOSO, 2013).

\subsubsection{Benefícios proporcionado pela Rede Baiana}

Os benefícios proporcionados pela rede tem sido diversos. Eles vão desde de benefícios individual, tanto pessoal quanto profissional, para os atores que fazem parte da rede, benefícios para os bancos, para a rede e para o movimento de economia solidária. Como benéficos pessoais foram apontados a participação em intercâmbios, encontros, reuniões, geração de renda e o recebimento 
de bolsas auxilio, que estimulam, motivam e aumenta a autoestima. Em relação ao benefícios profissionais foram mencionados as capacitações, trocas de experiências, ajuda mutua que melhoram a capacidade de atuação no dia a dia do banco. Ambas auxilia na melhoria da gestão do BCD, geram conhecimento, profissionalizam e abrem portas. Esses resultados corroboram com as colocações de Mance (2010) que afirma que as iniciativas que nascem da auto-organização vem auferindo grandes benéficos aos trabalhadores, propiciando motivação e promovendo a confiança mútua no outro, restaurando as condições objetivas e subjetivas para que as pessoas cumpram seu papel social.

Os benéficos para o movimento de economia solidária se confundem com o os benéficos da própria rede e do próprio banco, como o aumento do número de iniciativas, a recuperação e fortalecimento dos BCD fragilizados e maior visibilidade. Além deste benefícios, os bancos melhoraram sua gestão interna, aumentaram suas parcerias, estão mais articulados politicamente, capitaram mais recursos e aumentaram a oferta de produtos e serviços, beneficiando também as comunidades aos quais pertencem.

\subsubsection{A situação atual da rede}

A atual situação da rede no tocante ao seu fortalecimento ou enfraquecimento é um pouco controverso entre os membros da rede. Dos sete agentes entrevistados, quatro acreditam que a rede ainda está fortalecida, três acreditam que ela está enfraquecida. Os motivos que embasam a opinião de que a rede se encontra enfraquecida são: falta de responsabilidade dos membros com atividades da rede, falta de compromisso e falta de interesse. Os entrevistados acreditam que esse comportamento tem feito com que a rede produza bem mais aquém do que poderia produzir, caso houvesse uma participação mais sólida de todos os membros. Os adeptos a esse pensamento temem pela dissolução da rede por falta de recursos, uma vez que alguns membros não têm se empenhado em auxiliar nessa captação. A dissolução da rede, segundo esses membros, acarretaria, muito provavelmente, no encerramento dos bancos que já estão mais fragilizados.

Por outro lado, a maioria dos membros da rede, apesar de enxergar e apontar exatamente o mesmo problema, não acredita 
que esse motivo por si só é suficiente para afirmar que a rede está enfraquecida esse seria apenas um dos fatores. Ainda assim, acreditam que a Rede Baiana conseguiu construir um nome sólido e de credibilidade no estado da Bahia e no campo da economia solidária.

\subsubsection{Dificuldades e desafios da Rede Baiana}

As dificuldade e desafios apontados pelos membros da rede versaram sobre questões políticas e econômicas, desmobilização e fragilidade das entidades gestoras dos BCDs. Em relação a preocupação com o cenário políticos e econômico há consenso na rede que a atual conjuntura tem prejudicado a capacidade de articulação da rede devido à redução de recursos provenientes de editais públicos, principal fonte de financiamento das atividades da rede. A dificuldade promovida pela fragilidade da entidades gestoras foi apontada pela técnica da ITES como um dos pontos que tem prejudicado os bancos e consequentemente a rede. Quando a entidade se encontra fragilizada ela perde a capacidade de capitar recursos para o banco, o que ocasiona a redução da capacidade de atuação do banco, tanto no seu território quanto na rede.

Não há na rede um consenso em relação aos motivos que tem gerado o processo de desmobilização entre os atores para participar das atividades da rede, principalmente as reuniões. Foram apontados ao menos quatro motivos diferentes para a redução da participação nas atividades. Alguns bancos apontam que isso é fruto da falta de compromisso e desinteresse de alguns participantes. Entretanto outros atores apontaram que os principais motivos para a redução da participação está relacionado com a falta de estrutura dos bancos que estão mais fragilizados, como no caso dos bancos que possuem apenas uma agente de crédito e não podem paralisar suas atividades para participar das reuniões. Um terceiro motivo está relacionado as agendas dos próprios bancos e as agendas das entidades gestora que tem coincidido com as reuniões dos bancos. E o quarto e último motivo apontado, esse parecer ser um mais crítico, está relacionado a distância entre os bancos. Para participar de uma reunião de apenas um dia, algumas agentes precisam se ausentar por até três dias de suas atividades e duas famílias, o que é bastante complicado principalmente pelo fato de a maioria serem mulheres e terem filhos. 
O FORTALECIMENTO DOS BANCOS COMUNITÁRIOS A

PARTIR DA ORganizaÇÃo EM REDE: O CASO DA REDE BaIANA de BCDS

\begin{tabular}{|c|c|c|c|c|c|c|}
\hline \multirow{8}{*}{ 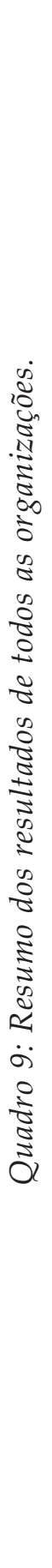 } & \multirow{3}{*}{ 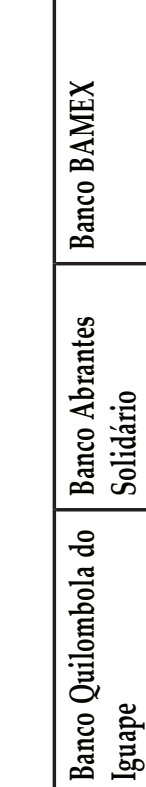 } & \multicolumn{3}{|l|}{ 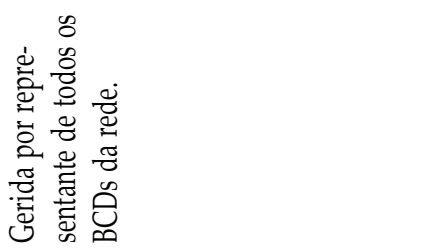 } & \multicolumn{2}{|l|}{ 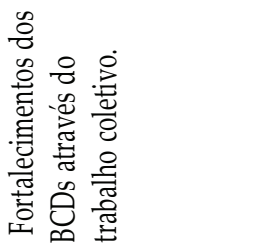 } \\
\hline & & 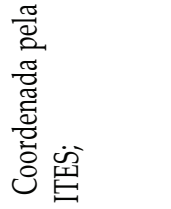 & \multicolumn{2}{|l|}{ 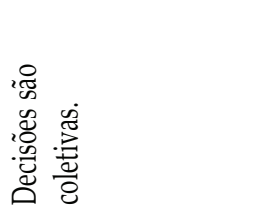 } & 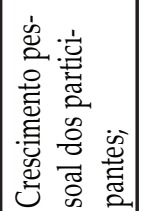 & 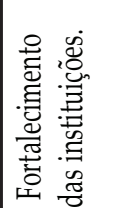 \\
\hline & & 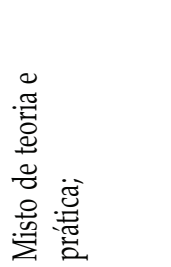 & 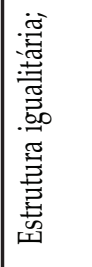 & 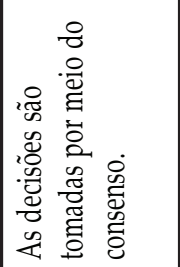 & 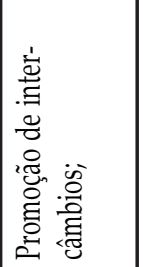 & 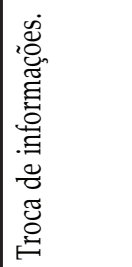 \\
\hline & 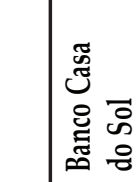 & 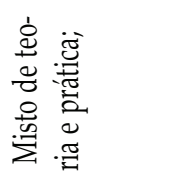 & 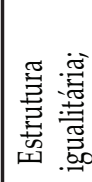 & 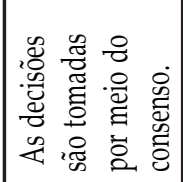 & \multicolumn{2}{|c|}{ 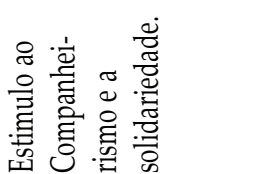 } \\
\hline & 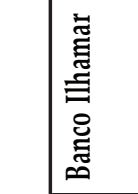 & \multicolumn{3}{|l|}{ 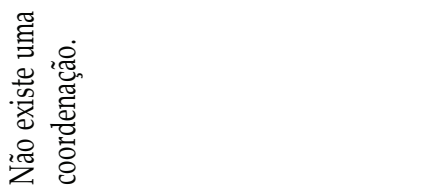 } & 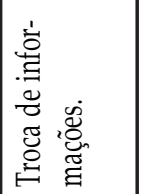 & 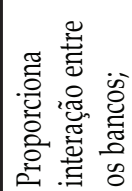 \\
\hline & 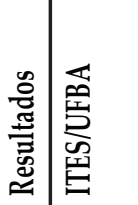 & 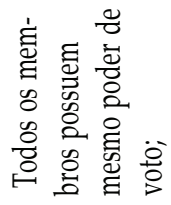 & 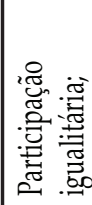 & 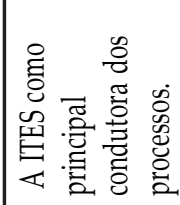 & 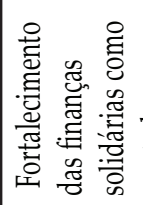 & \\
\hline & 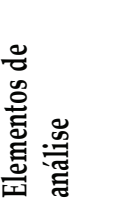 & \multicolumn{2}{|l|}{ 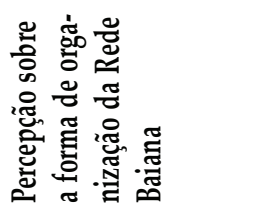 } & & \multicolumn{2}{|l|}{ 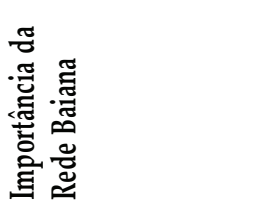 } \\
\hline & 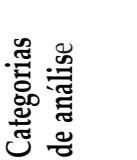 & \multicolumn{3}{|l|}{ 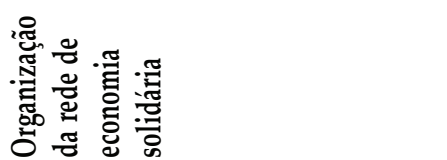 } & & \\
\hline
\end{tabular}


Magno Willams de Macedo Farias; Adrianne Garcia

Maria Elena Leon Olave

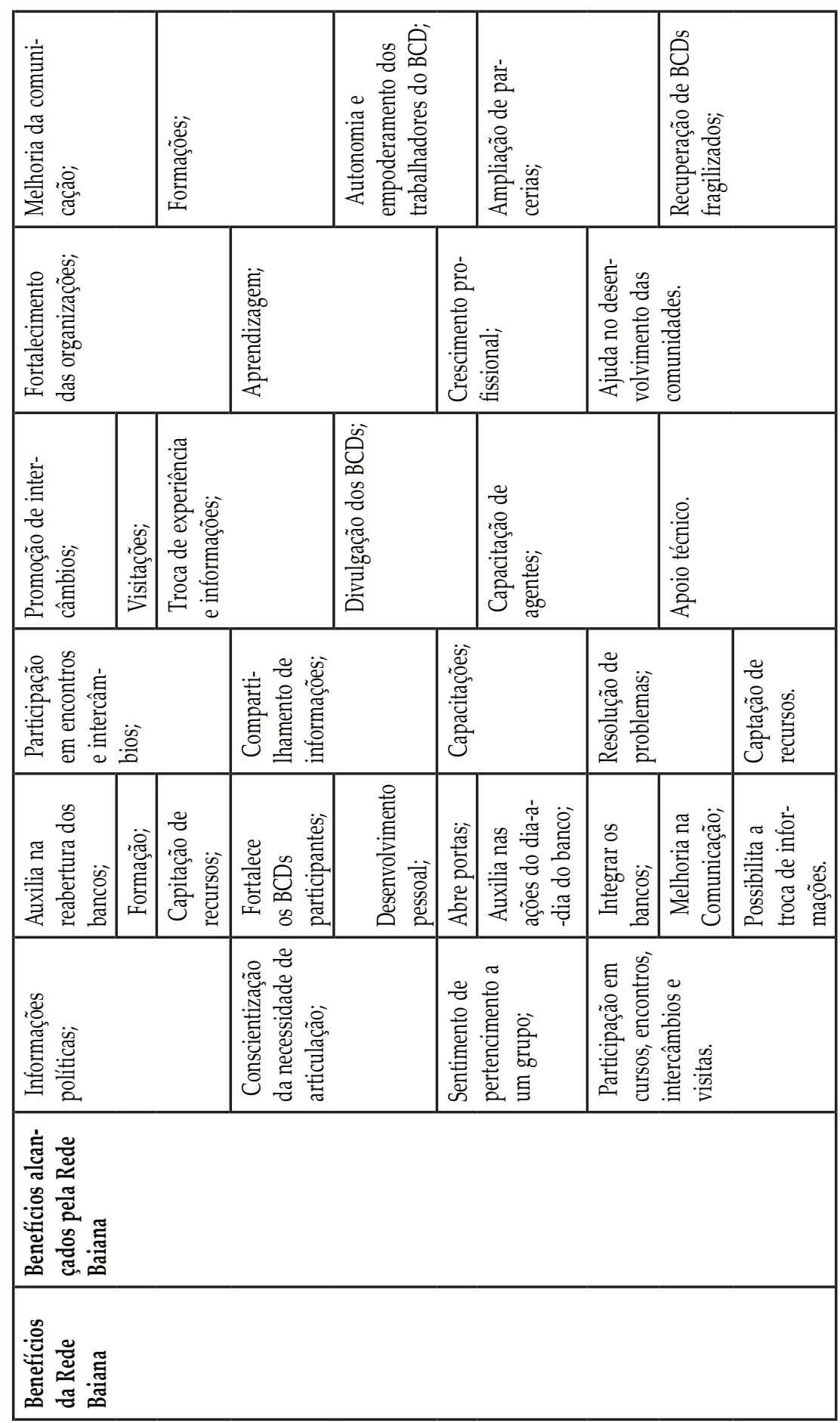

218 Organizações em contexto, São Bernardo do Campo, ISSNe 1982-8756 • Vol. 16, n. 31, jan.-jun. 2020 
O FORTALECIMENTO DOS BANCOS COMUNitÁRIOS A

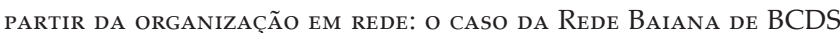

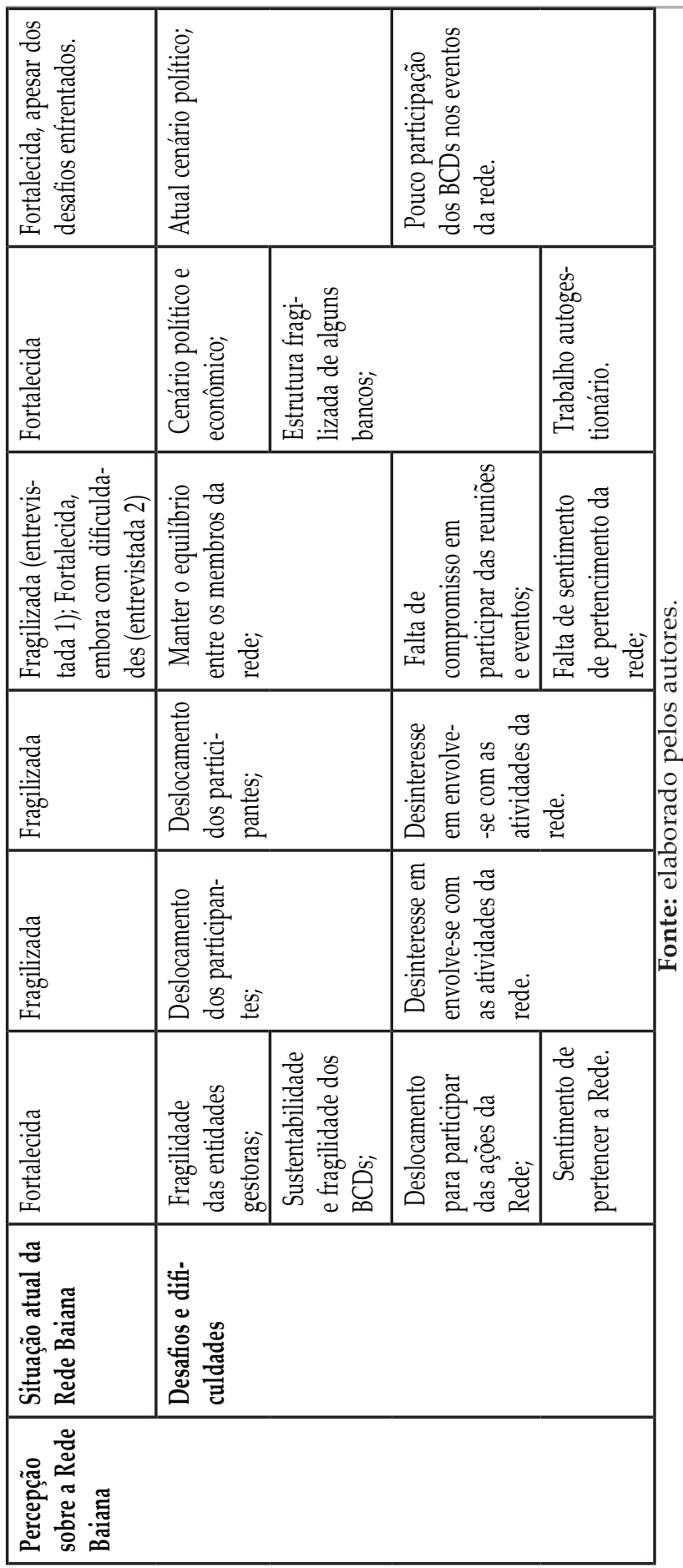

Organizações em contexto, São Bernardo do Campo, ISSNe 1982-8756 • Vol. 16, n. 31, jan.-jun. 2020219 


\section{CoNSIDERAÇõeS FINAIS E CONCLUSÃo}

Este estudo teve como objetivo analisar como a Rede Baiana de BCDs contribui para o fortalecimento dos bancos comunitários da Bahia. Segundo Braz e Cardoso (2013) a ação em rede passa a ser indispensável para o sucesso de um empreendimento solidário, além de ser um processo de transformação da sociedade e de sua capacidade de mobilização. A cooperação, nesse sentido, se torna um meio para superação de crises que vem assombram a sociedade ao longo dos séculos e visualiza uma nova realidade que pode ser construída através da coletividade.

A Rede Baiana de Bancos Comunitários tem colaborado de forma significativa para superar os desafios enfrentados pelos bancos, permitindo que seus participantes possam se articular, compartilhar informações, trocar experiências, receber auxilio técnico e acessar recursos. Além disso, tem patrocinado a participação de seus componentes em reuniões, encontros, oficinas, intercâmbios, visitas técnicas e cursos de capacitação, contribuindo para profissionalização dos trabalhados que atuam diretamente na execução das atividades do banco, melhorando a sua gestão. Suas ações de modo geral têm fortalecido os bancos existentes dando maior visibilidade e ampliando sua oferta de serviços, além de atuar no apoio à expansão dessas experiências com a constituição de novos bancos, fortalecendo tanto o movimento de economia solidária, como também a própria rede.

A rede, na opinião da maioria de seus atores, vem se fortalecendo ao longo dos anos, mas também apresentam desafios que podem levar a seu enfraquecimento, como o atual cenário político-econômico que tem reduzido sua capacidade de articulação, além do processo de desmobilização por parte de seus integrantes.

\section{Limitações e recomendações de estudo}

As limitações apresentadas por este trabalho se referem a dois aspectos, um relacionado ao tempo de pesquisa, que inviabilizou a participação dos pesquisares nas reuniões realizadas pela rede, o que permitiria uma triangulação de informações entre o conteúdo das entrevistas e a observação dos atores em conjunto. A segunda limitação está relacionada a análise de um único caso pelos pesquisadores o que limita maiores conclusões. Como sugestão de próximas pesquisa indicamos ampliação deste estudo com realização 
de estudos comparativos com outras redes de bancos e com outras redes de economia solidária. No tocante às suas contribuições, este estudo permitiu identificar as contribuições da rede baiana de bancos comunitários para seus participantes, além de contribuir para um melhor entendimento do funcionamento de uma rede de economia solidária, especificamente uma rede formada por bancos comunitários de desenvolvimento.

\section{REFERÊNCIAS}

BRAZ, C. L. R.; CARDOSO, O. O. Economia solidária e redes sociais: antigos fenômenos, novas feições. Revista Organizações em Contexto, v. 9, n. 17, p. 59-77, 2013.

CASTELlS, Manuel. A Sociedade em Rede. São Paulo, Paz e Terra, 1999.

CASSANDRE, M. P.; SENGER, C. M.; AMARAL, W. R.; NETA, E. V. F. Políticas Públicas para a geração de trabalho e renda: economia solidária no paradoxo entre oportunidade e oportunismo. Gestão e Sociedade. Belo Horizonte. V. 7, N. 17, p. 167-185. Maio/Agosto 2013.

CORAGGIO, J. L. ¿ Qué es lo económico y que que es otra política? In: Sidney, L.; Henriques, F. C. A economia solidária na América Latina: realidades nacionais e políticas públicas. Rio de Janeiro: Pró Reitoria de Extensão UFRJ. 2012. p. 21-46.

DOWBOR, Ladislou. Democracia econômica: um passeio pelas teorias. Fortaleza: Banco do Nordeste, 2007.

EISENHARDT, K. M. Building Theories from Case Study Research. The Academy of Management Review Vol. 14, No. 4 (Oct., 1989), pp. 532-550

FRANÇA FILHO, G. C. Banco Palmas 15 Anos: resistindo e inovando. Núcleo de Economia Solidária - NESOL-USP e Instituto Palmas - São Paulo: A9 Editora, 2013. P. 42-59.

FRANÇA FILHO, G. C. Papel dos Bancos Comunitários de Desenvolvimento na visão da sua rede. Documento de trabalho. Versão inicial 2010. Disponível em: rbbcd@googlegroups. com. Acesso em: 26 de dezembro de 2016.

FRANÇA FILHO, G. C.; CUNHA, E. V. - Incubação de redes locais de economia solidária: lições e aprendizados a partir da experiência do projeto eco-luzia e da metodologia da ites/ ufba. Revista O\&S. Salvador-BA, v.16 - n.51, p. 725-747 - Outubro/Dezembro - 2009.

FRANÇA FILHO, G. C.; LAVILLE, J.L. Economia solidária: uma abordagem internacional. Porto Alegre, Editora da UFRGS, 2004.

FRANÇA FILHO, G. C.; SANTANA, C. A. Bancos Comunitários de Desenvolvimento enquanto prática e dinâmica institucional. In: et al. Bancos comunitários de desenvolvimento (BCDs)como expressão de finanças solidárias: por uma outra abordagem da inclusão financeira. Fortaleza: Arte Visual, 2013. p. 50-96.

FREIRE, M. V. Banco Palmas 15 Anos: resistindo e inovando. Núcleo de Economia Solidária - NESOL-USP e Instituto Palmas - São Paulo: A9 Editora, 2013. P. 42-59. 
GAIGER, Luiz Inácio Germany. A associação econômica dos pobres como via de combate às desigualdades. CADERNO CRH, Salvador, v. 22, n. 57, p. 563-580, Set./Dez. 2009.

GODFREY, P. C. Toward a Theory of the Informal Economy. The Academy of Management Annals, v. 5, n. 1, p. 231-277. 2011.

GODOY,A.S. Introdução à pesquisa qualitativa e suas possibilidades. ERA-Revista de Administração de Empresas. São Paulo, v. 35, n.2, p. 57-63, 1995.

GRANOVETTER, M. The strength of weak ties. American Journal of Sociology, v. 78, n. 6, p. 1360-1380, 1973.

GUARDA, M. G. Cooperação Nas Redes Organizacionais. In: Arlete redivo; Fiorelo Picoli; Salli Baggenstoss. (Org.). Administração Nas Perspectivas de Mercado, Organização, Trabalho e Desenvolvimento Regional. 1ª ed.Cáceres: UNEMAT, 2010, v. 1, p. 129-141.

HART, K. Informal Income Opportunities and Urban Employment in Ghana. The Journal of Modern African Studies. v. 11. n. 1, p. 61-89. 1973.

HIGA, Willian Toshio Minatogawa. AS REDES DE ECONOMIA SOLIDÁRIA: CONVERGÊNCIAS E DIVERGÊNCIAS ENTRE A CIDADANIA E A INOVAÇÃO TECNOLÓGICA. In: I Simpósio Estadual Lutas Sociais na América Latina, 2005, Londrina/PR. Gepal - Ciências Humanas UEL, 2005.

IPEA - INSTITUTO DE PESQUISA ECONÔMICA APLICADA. O Sistema de Indicadores de Percepção Social (Sips). 2011. Disponível em: http://www.ipea.gov.br/portal/images/stories/ PDFs/SIPS/110112_sips_bancos.pdf. Acesso em: 19 dezembro. 2015

LAVILLE, C.; DIONNE, J. A construção do saber: manual de metodologia da pesquisa em ciências humanas / tradução Heloisa Monteiro e Francisco Settineri. - Porto Alegre: ARTMED, 1999

LAVILLE, J.; GAIGER.L. Economia Solidária. In: HESPANHA, Pedro [et ali.]. Dicionário Internacional da outra economia. Coimbra: Almedina, 2009, p. 162-168.

MACIEIRINHA, L. M. Dinamização da Cooperação Inter-Empresarial: Proposta de aumento de eficiência pela identificação e fecho de gaps Teoria - Concepção - Implementação. O CASO SISCOOP. Dissertação de Mestrado em Ciências Econômicas- Universidade do Porto- 2009.

MANCE, E. A. Redes de Colaboração Solidária. Petrópolis. Editora Vozes, 2002.

MANCE, E. A. Redes de Economia Solidária. In: Fundação Luís Eduardo Magalhães. Economia Solidária: desafios para um novo tempo. Salvador - FLEM, 2003. P. 71-82.

MELO NETO, J. J; MAGALHÃES, S. Bancos Comunitários de Desenvolvimento: uma rede sobre o controle da comunidade. Fortaleza: Arte Visual, 2007.

MINHOTO, Laurindo Dias; MARTINS, Carlos Estevam. As redes e o desenvolvimento social. Cadernos Fundap, n. 22, p. 81-101, 2001.

PROJETO ECOSMAR. Relatório Final: etapa I. Vera Cruz-Ba, maio, 2008b.

RIGO, A. S. Autogestão. In: BOULLOSA, Rosana de Freitas (org.). Dicionário para formação em gestão social. Salvador: CIAGS/UFBA, 2014.p. 21-23. 
RIGO, A. S. Moedas sociais e bancos comunitários no brasil: aplicações e implicações, teóricas e práticas. Tese (Doutorado em Administração) - Universidade Federal da Bahia, Salvador, 2014. RIGO, A. S.; CANÇADO, A. C. Gestão social e construção de espaços públicos: reflexões a partir da Rede Brasileira de Bancos Comunitários do Brasil . Administração Pública e Gestão Social, v. 7, n. 1, p. 38-44, 2015.

RIGO, A. S., FRANÇA FILHO, G. C.; LEAL, L. P. Os bancos comunitários de desenvolvimento na política pública de finanças solidárias: apresentando a realidade do Nordeste e discutindo proposições. Desenvolvimento em Questão. v. 13, n. 31, p.70-107, 2015.

SINGER, P. Banco Palmas 15 Anos: resistindo e inovando. Núcleo de Economia Solidária NESOL-USP e Instituto Palmas - São Paulo: A9 Editora, 2013. P. 27-31.

SIQUEIRA, D. M.; COSTA, B. K.; VIEIRA, A. M. Redes de Poder em Empreendimentos Solidários de Reciclagem. Revista de Administração da Unimep, v. 15, n. 2, p. 130-151, 2017.

SIQUEIRA, D. M.; VIEIRA, A. M.; CARMONA, V. C. Rede de confiança e amizade: relações de trabalho em uma cooperativa. Revista CESUMAR, v. 18, p. 299-318, 2013.

VERSCHOORE, Jorge R. Redes de Cooperação Interorganizacionais: a identificação de atributos e benefícios para um modelo de gestão. Universidade Federal do Rio Grande do Sul. Tese de Doutorado, 2006.

VIEIRA, A. M.; RIVERA, D. P. B. A Hermenêutica no Campo Organizacional: duas possibilidades interpretativistas de pesquisa. Revista Brasileira de Gestão de Negócios, v. 14, n. 44, p. 261-273, 2012.

YIN, R. K. Estudo de caso: planejamento e métodos. 5. ed. Porto Alegre: Bookman, 2015. 320 p.

Recebido em: 19-9-2017

Aprovado em: 12-11-2020

Avaliado pelo sistema double blind review.

Disponível em http://mjs.metodista.br/index.php/roc 